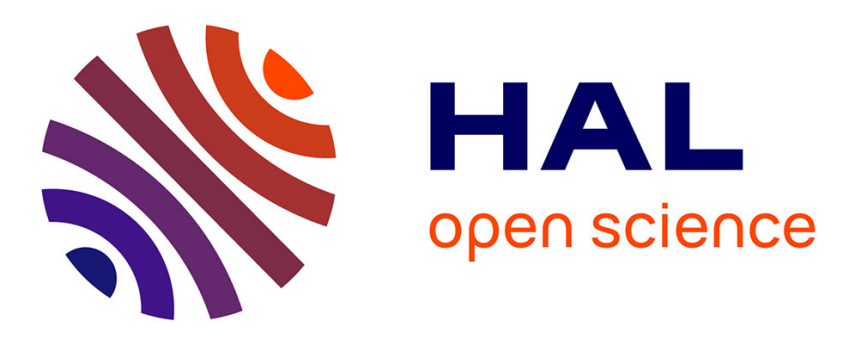

\title{
Recent developments in heterocycle labeling with carbon isotopes
}

\author{
Antonio del Vecchio, Gianluca Destro, Frédéric Taran, Davide Audisio
}

\section{To cite this version:}

Antonio del Vecchio, Gianluca Destro, Frédéric Taran, Davide Audisio. Recent developments in heterocycle labeling with carbon isotopes. Journal of Labelled Compounds and Radiopharmaceuticals, 2018, 61 (13), pp.988-1007. 10.1002/jlcr.3666 . cea-02420525

\section{HAL Id: cea-02420525 https://hal-cea.archives-ouvertes.fr/cea-02420525}

Submitted on 20 Dec 2019

HAL is a multi-disciplinary open access archive for the deposit and dissemination of scientific research documents, whether they are published or not. The documents may come from teaching and research institutions in France or abroad, or from public or private research centers.
L'archive ouverte pluridisciplinaire HAL, est destinée au dépôt et à la diffusion de documents scientifiques de niveau recherche, publiés ou non, émanant des établissements d'enseignement et de recherche français ou étrangers, des laboratoires publics ou privés. 


\title{
Recent Developments in Heterocycles Labeling with Carbon Isotopes
}

\author{
Antonio Del Vecchio, ${ }^{\mathrm{a}}$ Gianluca Destro, ${ }^{\mathrm{a}}$ Frédéric Taran, ${ }^{\mathrm{a}}$ Davide Audisio ${ }^{\mathrm{a} *}$
}

${ }^{a}$ CEA-Saclay, JOLIOT, Service de Chimie Bioorganique et de Marquage, Gif sur Yvette, F91191,

France.

$\S$ These authors contributed equally.

*Correspondence to: Davide Audisio, CEA-Saclay, JOLIOT, Service de Chimie Bioorganique et de Marquage, Gif sur Yvette, F-91191, France.

E-mail : davide.audisio@cea.fr

\begin{abstract}
Heterocycles play an essential role in modern pharmaceutical and agrochemical developments, representing a very common structural unit in marketed drugs. Over the 46 new drugs approved in 2017 by the FDA, 25 contain in their structure an heterocyclic core. The development of novel and straightforward labeling strategies for the effective insertion of carbon isotopes into heterocylic scaffolds is an inspiring and vibrant field of research. The use of carbon-11, carbon-13 and carbon-14 isotopes is well established in life science and particularly in pharmaceutical and agrochemical industry. Their introduction into small organic molecules represents a crucial step for the radiochemists. Since the labeling should occur in metabolically stable positions and in the shortest synthetic route, their incorporation into the heterocycles represent a viable solution. This review summarizes recent contributions to this area of research through the analysis of different industrial and academic cases.
\end{abstract}

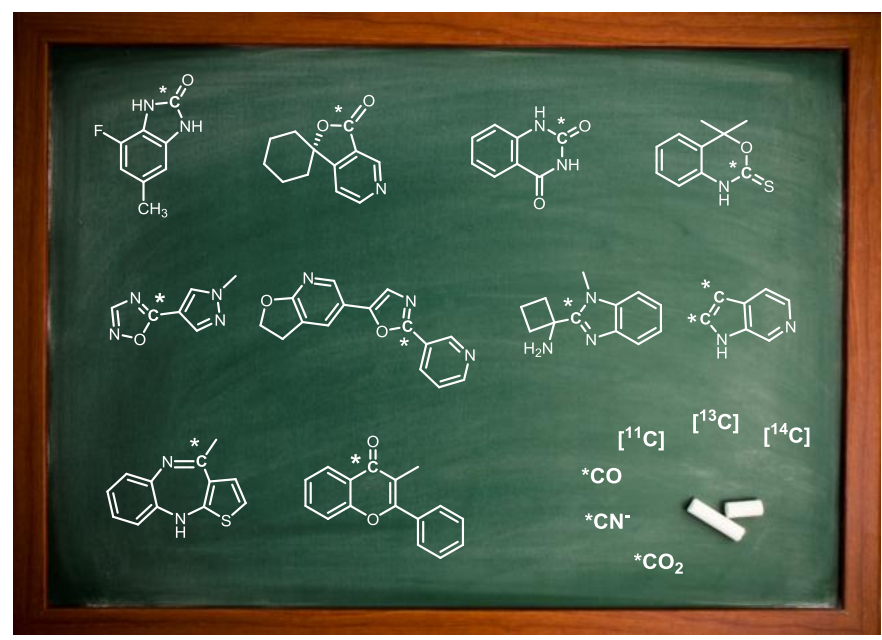

Keywords: isotopic labeling; carbon-14; carbon-11 carbon-13, heterocycles 


\section{Introduction}

Heterocycles play an essential role in modern pharmaceutical and agrochemical developments, representing very common motif in marketed drugs and in the drug discovery process $^{1}$ : over $80 \%$ of top small molecule drugs by US retail sales in 2010 , contained at least one heterocyclic fragment in their structures ${ }^{2}$. In 2017, the FDA approved 46 new drugs, the highest total in more than two decades. Remarkably, 25 of such new molecules contain in their structure an heterocyclic moiety. ${ }^{3}$ Carbon isotopes (carbon-11, carbon-13 and carbon-14) are ideal tools for the labeling of small organic molecules allowing the traceless insertion of a mass or a radioactive tag without modifications of their properties and activity. Their efficient insertion of such labels into heterocycles has been a major challenge over the years. Synthetic access to heterocycles is generally well established in organic chemistry, but its implementation to carbon isotope labeling is often complicated by the different specifications of each radionuclide, notably the half-life and the fundamental sources of the isotope. Despite sharing the same reactivity, the three isotopes of carbon often requires specific strategies, with different challenges and diverse outcomes. As a direct consequence, the synthesis must be revisited and optimized in order to meet such strict requirements.

In this review, the recent developments in heterocycles labeling with carbon isotopes are described, focusing on methods that allow the incorporation of the isotope within the heterocyclic scaffold. Due to the large amounts of publications reported in the literature, the authors decided to select recent works describing the most general and straightforward approaches. We apologize for those brilliant pieces of work that could not be included in the manuscript.

\section{Synthesis of ${ }^{11} \mathrm{C}$ labelled heterocycles}

Positon emission tomography (PET) is a non-invasive molecular imaging technique used to study and visualize human physiology by the detection of positron-emitting radiopharmaceuticals ${ }^{4}$. Carbon-11 is a short-live positron-emitting radionuclide $\left(t_{1 / 2}=20.4\right.$ min) ${ }^{5}$ and radiotracers labeled with ${ }^{11} \mathrm{C}$ are widely used for the early diagnosis of cancer, monitoring therapeutic response to cancer treatment, and pharmacokinetic investigations of anticancer drugs ${ }^{6}$. However, the narrow half-life window make high-specific-activity radiopharmaceuticals labeled with carbon-11 some of the most synthetically challenging to prepare. One major ${ }^{11} \mathrm{C}$-precursor utilized in synthesis is $\left[{ }^{11} \mathrm{C}_{\mathrm{CO}_{2}}\right.$ (the other being $\left[{ }^{11} \mathrm{C}_{\mathrm{CH}_{4}}\right)^{7}$. To date the most frequently used method for the introduction of ${ }^{11} \mathrm{C}$ into organic molecules the methylation ${ }^{8}$. Methylations with this isotope are limited to the labelling of molecules at functional groups at peripheral atomic positions. Hence, alternative labelling pathways are mainly pursued when the target molecule does not contain a suitable functional group for methylation or if rapid in vivo metabolism of the tracer forces other atomic positions to be investigated ${ }^{9}$.

Hit and lead small molecules and drugs often contain an heterocycles core in their structure, for these reasons new strategies to selectively introduce carbon-11 are highly desirable. The chemistry of carbon monoxide is well established and metal catalyzed carbonylation reactions have been widely explored. However, radiochemistry using $\left[{ }^{11} \mathrm{C}\right] \mathrm{CO}$ presents 
unique challenges that are not encountered with regular carbonylation reactions ${ }^{10,11}$. Traditionally, carbonylations are performed at elevated pressures and temperatures, with extended reaction times (typically $>12 \mathrm{~h}$ ) in order to improve the poor solubility of $\mathrm{CO}$ in common organic solvents and so maximize chemical yields. The short half-life of this isotope precludes such long reaction times and the miniscule amounts of isotopically labelled $\left[{ }^{11} \mathrm{C}\right] \mathrm{CO}$ result in very low partial pressures, which disfavor its solubility and reactivity. $\left[{ }^{11} \mathrm{C}\right]-$ carbon monoxide is therefore challenging both in terms of handling and reactivity ${ }^{12}$. In the next section, the more recent methods utilizing $\left[{ }^{11} \mathrm{C}\right] \mathrm{CO}$ in metal catalyzed ring closure as late stage labelling procedure are emphasized.

\section{Metal catalyzed carbonylation}

Originally developed by Heck in $1974^{13,14}$, the palladium-catalyzed carbonylation has been used to access to a broad range of carbonyl-containing heterocycles such as benzoimidazolone, lactones, lactams etc., moieties widely spread in drug scaffolds and bioactive molecules. As previously mentioned, a major drawback of carbon monoxide is its poor solubility in organic solvent. A number of innovative solutions have been described to overcome this limitation, such as the use of the high-pressure method (i.e. performing the reaction in autoclave reactors) ${ }^{15}$ increasing mass transfer between the gas and liquid phases by expanding the interfacial contact area, by means of microfluid reactors and packed tube reactors. Another solution consists in its chemical trapping, in order to catch the carbon monoxide generated. In 2004, a $\mathrm{BH}_{3}$ THF solution was used to trap [ $\left.{ }^{11} \mathrm{C}\right]$-carbon monoxide at room temperature in the form of a borane adduct. More recently, a copper (I) scorpionate complex, with a tris(pyrazolyl)borate ligand, has been used as efficient $\left[{ }^{11} \mathrm{C}\right] \mathrm{CO}$ trapping agents. The tridentate geometry of the ligand leaves the metal center with a vacant coordination site for the interaction of carbon monoxide. This method has proven to give higher and more reliable trapping efficiencies than the borane one, in addition to its technical simplicity ${ }^{16}$. Following the trapping procedures, palladium-mediated carbonylation reactions were performed to assemble a M1 muscarinic acetylcholine receptor radiotracer. $\left[{ }^{11} \mathrm{C}\right]-$ GSK1034702 has been synthetized from the aniline precursor 1 by ring closure of a substitued benzoimidazolone ${ }^{17}$ (SCHEME 1a). From an experiment point of view, the $\left[{ }^{11} \mathrm{C}\right]$-carbon monoxide/helium stream mixture was passed through a toluene solution containing the copper catalyst; meanwhile, the carbonylation coupling reagents (catalyst, aniline $\mathbf{1}$ and DMF) were heated in a separate vial at $100{ }^{\circ} \mathrm{C}$ for $5 \mathrm{~min}$. Following $\left[{ }^{11} \mathrm{C}\right] \mathrm{CO}$ delivery, the carbonylation reagents were injected into the vial and the vessel was sealed and heated (typically at $120{ }^{\circ} \mathrm{C}$ ) for 5 minutes, obtaining the desired radiotracer with the radiochemical yield of $6 \%$. 
a)<smiles>Cc1cc(F)c(N)c(NC2CCN(C3CCOCC3)CC2)c1</smiles>

1
$\frac{\operatorname{CuTp}\left({ }^{11} \mathrm{Co}\right)}{\mathrm{Pd}\left(\mathrm{PPh}_{3}\right)_{2} \mathrm{Cl}_{2}}$<smiles>Cc1cc(F)c2[nH]c(=O)n(C3CCN(C4CCOCC4)CC3)c2c1</smiles>

$\left[{ }^{11} \mathrm{C}\right]-$ GSK1034702

$\mathrm{RCY}=6 \%$

b)

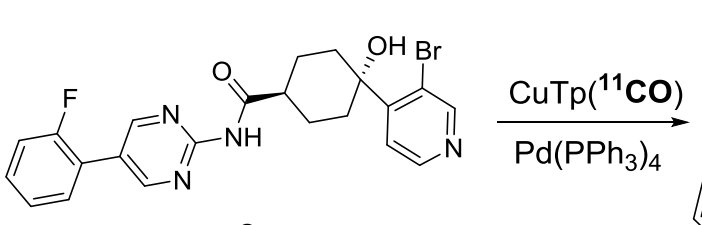

2

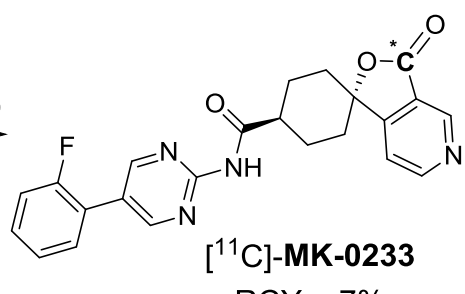

$\mathrm{RCY}=7 \%$

SCHEME 1 a) Synthesis of M1 muscarinic acetylcholine receptor radiotracer $\left[{ }^{11} \mathrm{C}\right]$ GSK1034702 and b) $\left[{ }^{11} \mathrm{C}\right]-\mathrm{MK}-0233 ; \mathrm{CuTp}=$ copper (I) scorpionate complex.

The mechanism of the palladium(II)-catalyzed oxidative carbonylation reaction is thought to proceed via formation of an isocyanate intermediate from a palladium carbamoyl species, which subsequently reacts with a free amine molecule (either primary or secondary) to generate the urea. Because secondary amines are unable to form isocyanates, tetrasubstituted ureas cannot form.

By means of a similar strategy, S. Kealey et al. reported the labeling of lactone $\left[{ }^{11} \mathrm{C}\right]-\mathrm{MK}$ 0233, a ligand for the neuropeptide Y5 receptor (SCHEME 1b) ${ }^{18}$.

T. Cornilleau et al. described in 2015 the use of this carbonylative strategy to develop a last stage labeling of biomolecules. The authors conceived a general intermediate $\mathbf{3}$ bearing an alkyne moiety which could be easily functionalized by means of the notoriously famous copper catalyzed alkyne azide cycloaddition $(\mathrm{CuAAC})^{19}$ with a variety of biomolecules. The triazole derivatives were further utilized for the insertion of a carbon isotope tag and formation of the desired five membered lactone $\left[{ }^{11} \mathrm{C}\right]-4$. This strategy was successfully validated on a large variety of examples with carbon-13. A proof of concept with carbon-11 was obtained on two representative substrates $\mathbf{3 a}$ and $\mathbf{3 b}$ that were labeled with high radiochemical purity, showing the high chemo selectivity and robustness of the carbonylation $\left(\right.$ SCHEME 2) ${ }^{20}$. 


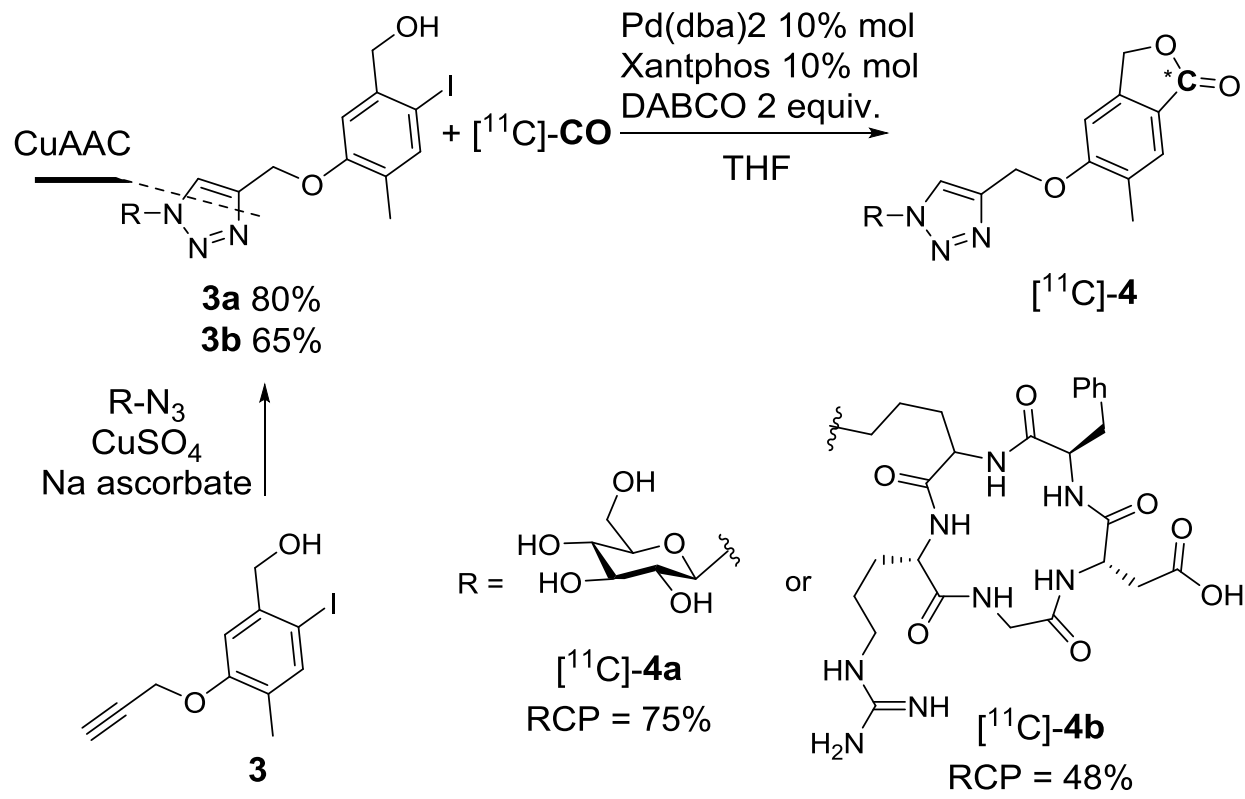

SCHEME 2 Last step labeling of biomolecules with $\left[{ }^{11} \mathrm{C}\right] \mathrm{CO}$ via palladium catalysis.

Recently, a novel ${ }^{11} \mathrm{C}$-carbonylation protocol has been developed by Eriksson et al., which exploits the high solubility of xenon gas in organic solvents as an effective way of transferring the radioactive gas to a small volume reaction vial. The use of xenon as a delivery gas allows for quantitative transfer of carbon monoxide from a silica pre-trap into tiny amount of solvent volumes without significant xenon pressure build-up. This method is particularly attractive because it avoids the use of additional chemical trapping reagents or of a high-pressure microautoclave. Moreover the system has been used for both palladium and rhodium ${ }^{11} \mathrm{C}$ carbonylative coupling reactions to generate a series of simple amides, ureas and esters ${ }^{21}$.

Rhodium is a catalytically active transition metal, used to perform a wide variety of $\mathrm{C}-\mathrm{C}$ bond forming reactions ${ }^{22}$. Although rhodium-catalyzed carbonylation reactions are exploited in both industry and academia, their application in the synthesis of fine chemicals is less extensive than palladium. Rhodium-mediated reactions are generally performed between an azide and either an amine or an alcohol to form ${ }^{11} \mathrm{C}$-carbonyl labeled ureas and carbamates. As reported by $\mathrm{J}$. Veerbek et al. this protocol was successfully applied to the cyclization of 6 into $\left[{ }^{11} \mathrm{C}\right]$-phenytoin in $22 \%$ RCY (SCHEME 3) ${ }^{23}$.

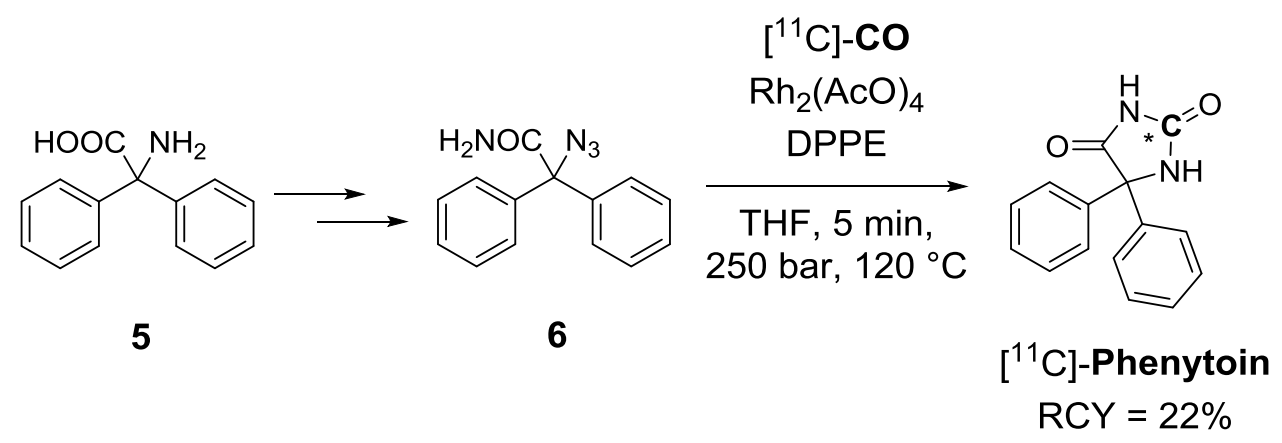

SCHEME 3 Synthesis of $\left[{ }^{11} \mathrm{C}\right]$-phenytoin via rhodium-catalyzed cyclization. 


\section{Metal - free carbonylation}

Besides $\left[{ }^{11} \mathrm{C}\right]-\mathrm{CO}$, another reagent utilized to introduce labelled-carbonyl moieties in heterocycles is $\left[{ }^{11} \mathrm{C}\right]$-phosgene. First reported in the $1970 \mathrm{~s}$, the reactivity of $\left[{ }^{11} \mathrm{C}\right]-\mathrm{COCl}_{2}$ is well-established and allowed the insertion of a labeled carbonyl between two heteroatoms without the need for dehydration, redox operations or transition metal catalysis ${ }^{24}$.

A variety of ${ }^{11} \mathrm{C}$-carbonyl containing heterocycles are directly accessible using labelled phosgene, including imidazolones, oxazolidinones and an oxazolidindione. Among the earliest applications, the labeling of urea (by treatment with aqueous ammonia), a valuable precursor to labeled barbituric acids and nucleosides such as thymidine. Similarly, symmetric $\left[{ }^{11} \mathrm{C}\right]$-carbonates and $\left[{ }^{11} \mathrm{C}\right]$-ureas are readily prepared from $\left[{ }^{11} \mathrm{C}\right]$-phosgene, as well as the heterocycles hydantoins and imidazolones (SCHEME 4) ${ }^{25,26}$.

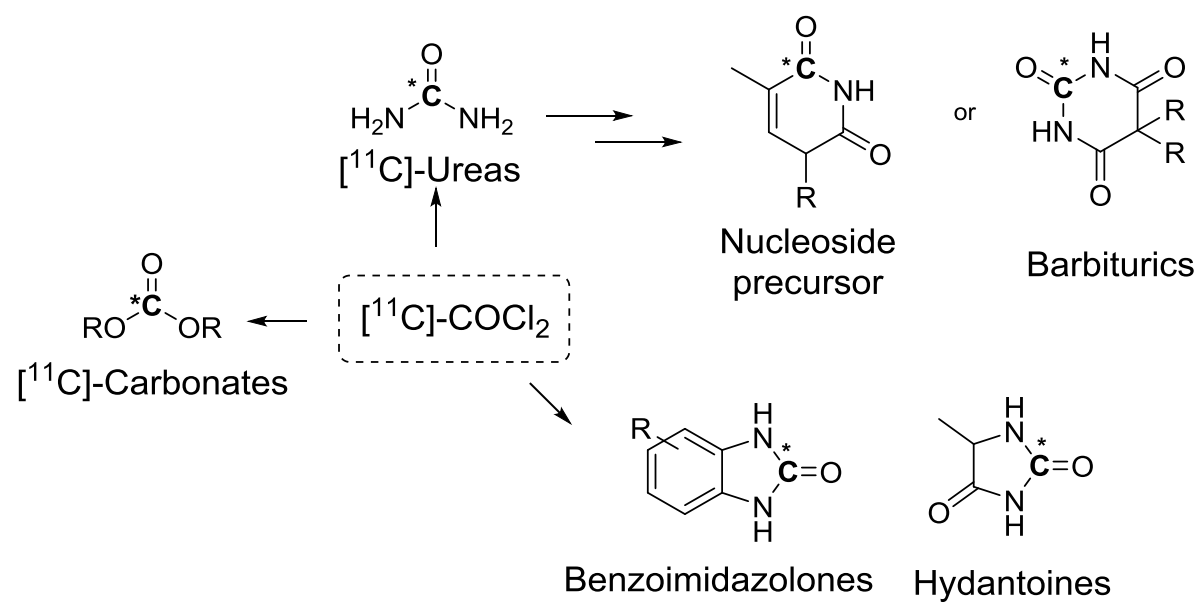

SCHEME 4 Radiolabeling using $\left[{ }^{11} \mathrm{C}\right]$-phosgene.

One selected example highlighting of the use of phosgene as effective tool for the radiosynthesis is depicted in SCHEME 5. Compound $\left[{ }^{11} \mathrm{C}\right]-8$, a PET radiotracer studied for imaging NR2B containing NMDA receptors, was obtained from the corresponding ophenylenediamine (7) in 30-40\% $\mathrm{RCY}^{27}$.

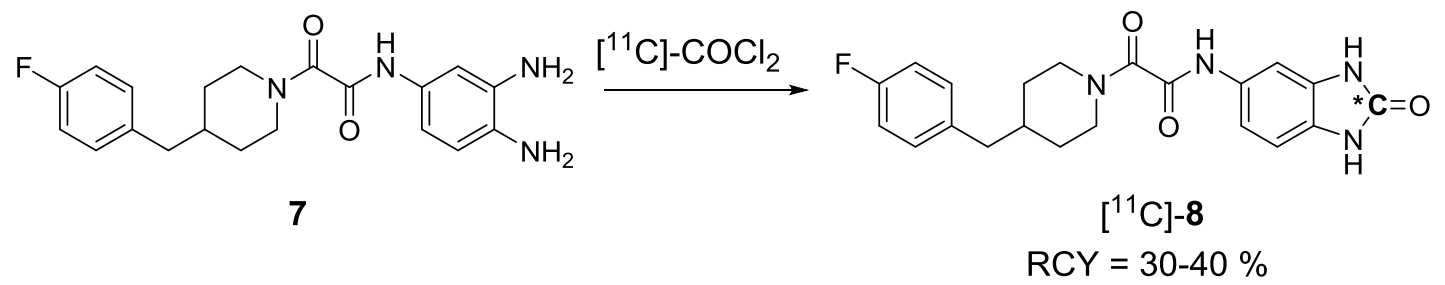

SCHEME 5 Synthesis of PET radiotracer $\left[{ }^{11} \mathrm{C}\right]-\mathbf{8}$.

Despite its remarkable reactivity, $\left[{ }^{11} \mathrm{C}\right]$-phosgene requires the utilisation of specialized apparatus and a complicated production, thus limiting a broad utilization. $\left[{ }^{11} \mathrm{C}\right]$-carbon dioxide, is a highly convenient reagent in radiolabeling: its direct utilization and its functionalization to more reactive synthons are indeed highly desirable. 
In 2012, Schou et al. reported the conversion of labelled carbon dioxide directly in the formiate $\left[{ }^{11} \mathrm{C}\right]-9$ using lithium triethylborohydride, as reducing agent; subsequent reaction in presence of bidentate nucleophiles, such as benzene-1,2-diamine, allowed the formation of the corresponding benzimidazole $\left[{ }^{11} \mathrm{C}\right]-\mathbf{1 1}$ in $96 \%$ radiochemical purity ${ }^{28}$ (SCHEME 6).

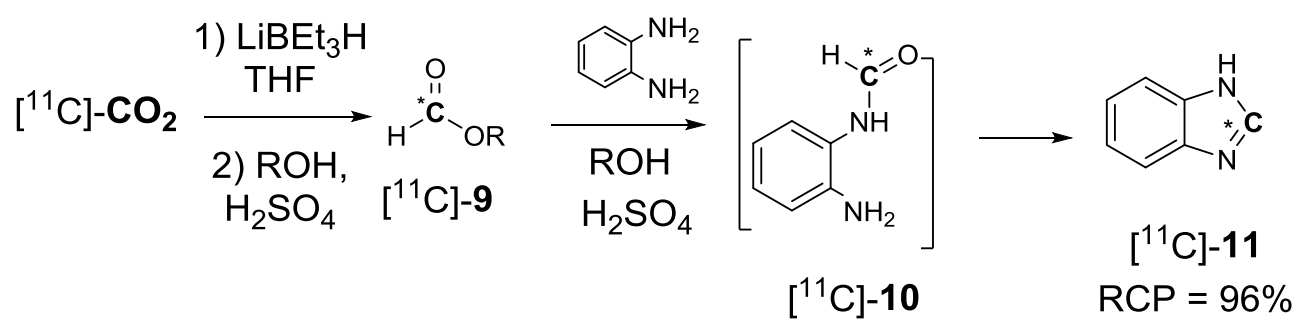

SCHEME 6 General preparation of $\left[{ }^{11} \mathrm{C}\right]-\mathbf{1 1}$.

Similarly to $\mathrm{CO}$, carbon dioxide is poorly soluble in polar organic solvents. It has been shown that the utilization of organic nitrogenous bases such as BEMP or DBU help the fixation of radiolabeled $\mathrm{CO}_{2}$ in DMF and other polar solvents ${ }^{29,30}$.

Two examples were recently reported from Mossine et al. ${ }^{31}$ where new radiotracers containing cyclic urea rings were synthetized using $\mathrm{CO}_{2}$ fixation. $\left[{ }^{11} \mathrm{C}\right]-\mathrm{QZ}$, a radiotracers for glutaminyl cyclase (QC) and glycogen synthase kinase-3 (GSK-3), was obtained from the amine precursor 12 and $\mathrm{POCl}_{3}$ as dehydrating agent. The intermediate isocyanate, formed in the sequence, was immediately trapped to obtain the final compound in $1 \% \mathrm{RCY}$.

The same conditions were used for the radiotracer $\left[{ }^{11} \mathrm{C}\right]$-Tideglusib, an inhibitor of GSK-3. In this example the isocyanate $\left[{ }^{11} \mathrm{C}\right]-\mathbf{1 4}$ was reacted with benzyl isothiocyanate and subsequently underwent ring formation obtaining the final drug in 2\% RCY (SCHEME 7).

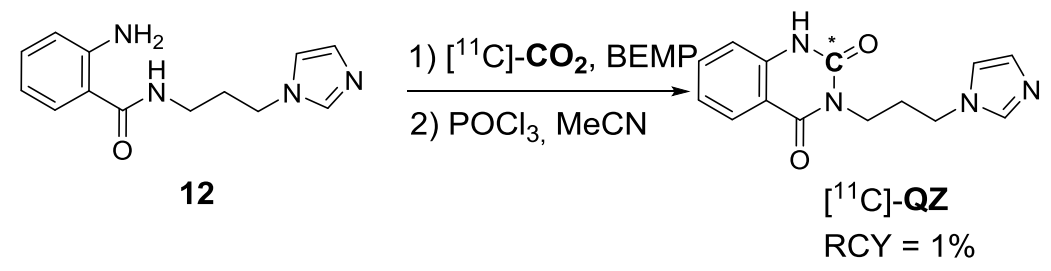

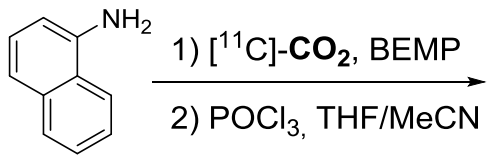

13

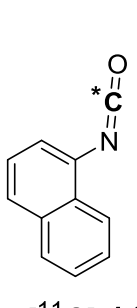

$\left[{ }^{11} \mathrm{C}\right]-14$

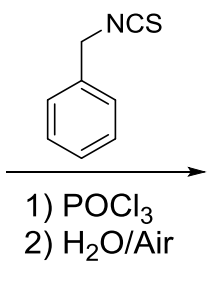

1) $\mathrm{POCl}_{3}$

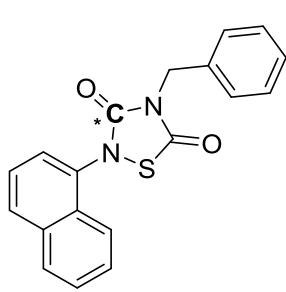

$\left[{ }^{11} \mathrm{C}\right]$-Tideglusib

$\mathrm{RCY}=2 \%$

SCHEME 7 Synthesis of $\left[{ }^{11} \mathrm{C}\right]-\mathrm{QZ}$ a PET radiotracer for glutaminyl cyclase, and the inhibitor of glycogen synthase kinase-3 $\left[{ }^{11} \mathrm{C}\right]$-Tideglusib.

In 2015, the Miller group reported a rapid and high yielding route to carbon-11 labeled carbon disulfide. This methodology shows many of the desirable characteristics for PET labeling: ease of synthesis and handling, high reactivity and the potential to radiolabel a wide range of 
compounds ${ }^{32} \cdot\left[{ }^{11} \mathrm{C}\right] \mathrm{CS}_{2}$ is obtained directly from radiolabeled methyl iodide, where the gas phase is reacted with phosphorus pentasulfide $\mathrm{P}_{2} \mathrm{~S}_{5}$ at $380{ }^{\circ} \mathrm{C}$ and then collected in an acetonitrile solution ${ }^{33}$.

From a reactivity standpoint, carbon disulfide is a good electrophile with relatively weak $\mathrm{C}=\mathrm{S}$ double bonds, comparably more reactive than carbon dioxide. Most of the fine chemicals obtained using this synthon belong to the thiourea family, known precursors heterocyclic structures. A notable example is the efficient late stage labeling of $\left[{ }^{11} \mathrm{C}\right]$-Tanaproget, a progesterone receptor agonist, which was achieved from the corresponding aniline precursor 15 in $14 \% \operatorname{RCY}^{34}$ (SCHEME 8).

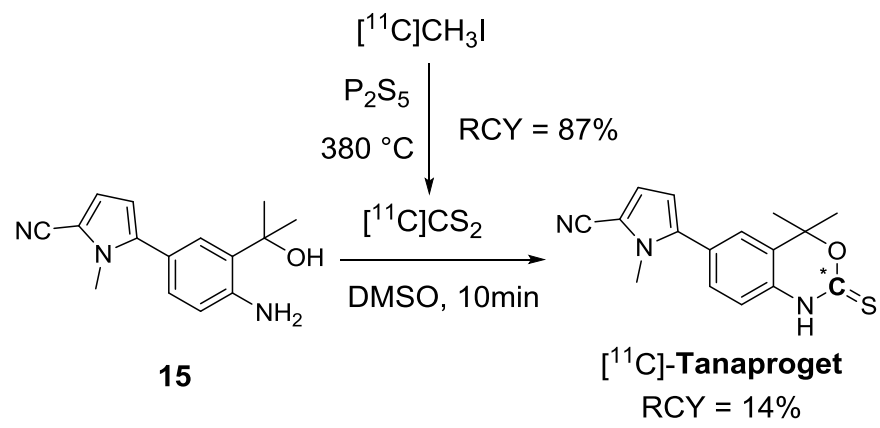

SCHEME 8: Radiosyntheis of progesterone receptor agonist $\left[{ }^{11} \mathrm{C}\right]$-Tanaproget.

As highlighted here, carbon-11 labeling of heterocycles still represent a monumental challenge today. The methods available are rather limited and carbonylative cross coupling are the most effective tool reported so far. We believe there is still ample room for improvement and methodologies favoring the use of $\left[{ }^{11} \mathrm{C}\right] \mathrm{CO}_{2}$ might be encouraged.

\section{Synthesis of ${ }^{14} \mathrm{C}$ labelled heterocycles}

Carbon-14 is a long-lived radioactive isotope of carbon (half-life 5730 years) which has been exploited for decades in a wide range of applications, especially in life sciences, including research and development of pharmaceuticals and crop protection agents. ${ }^{35}$

While compounds labeled with tritium are used during basic research studies, carbon-14 labeling is an ideal tool for in vitro and in vivo characterization of adsorption, distribution, metabolism ad excretion (ADME) in animals and humans, due to its resistance to metabolic cleavage $^{36,37}$. Unfortunately, the introduction of this radioisotope into organic molecules often requires harsh and multi-step synthetic procedures from the most readily accessible sources of the isotope: $\left[{ }^{14} \mathrm{C}\right]$-barium carbonate, $\left[{ }^{14} \mathrm{C}\right]$-carbon dioxide and $\left[{ }^{14} \mathrm{C}\right]$-potassium cyanide

An interesting example of heterocyclic labelling with carbon-14 was reported in 2014 by Barrel and co-workers for the synthesis of $\left[{ }^{14} \mathrm{C}\right]$-Avagacestat, a $\gamma$-secretase inhibiting drug reported by Bristol-Meyer-Squibb for the treatment of Alzheimer disease ${ }^{38}$. In this multi-step synthesis, the carbon label was introduced in the very beginning by a palladium-mediated cross coupling reaction between 4-bromo-2-fluorotoluene (16) and $\left[{ }^{14} \mathrm{C}\right]-\mathrm{Zn}(\mathrm{CN})_{2}$, synthetized in one quantitative step from $\left[{ }^{14} \mathrm{C}\right]-\mathrm{KCN}$ (SCHEME 9) ${ }^{39}$. The nitrile derivative $\left[{ }^{14} \mathrm{C}\right]-\mathbf{1 7}$ was readily converted in to the corresponding hydroxylamine $\left[{ }^{14} \mathrm{C}\right]-\mathbf{1 8}$, which was 
subsequently cyclized in presence of boron trifluoride and trimethyl orthoformate, affording the desired labelled 1,2,4-oxadiazole derivative $\left[{ }^{14} \mathrm{C}\right]-\mathbf{1 9}$. In three additional steps, $\left[{ }^{14} \mathrm{C}\right]-\mathbf{1 9}$ could be converted into the labeled Avagacestat with $13.77 \mathrm{mCi}$ produced.

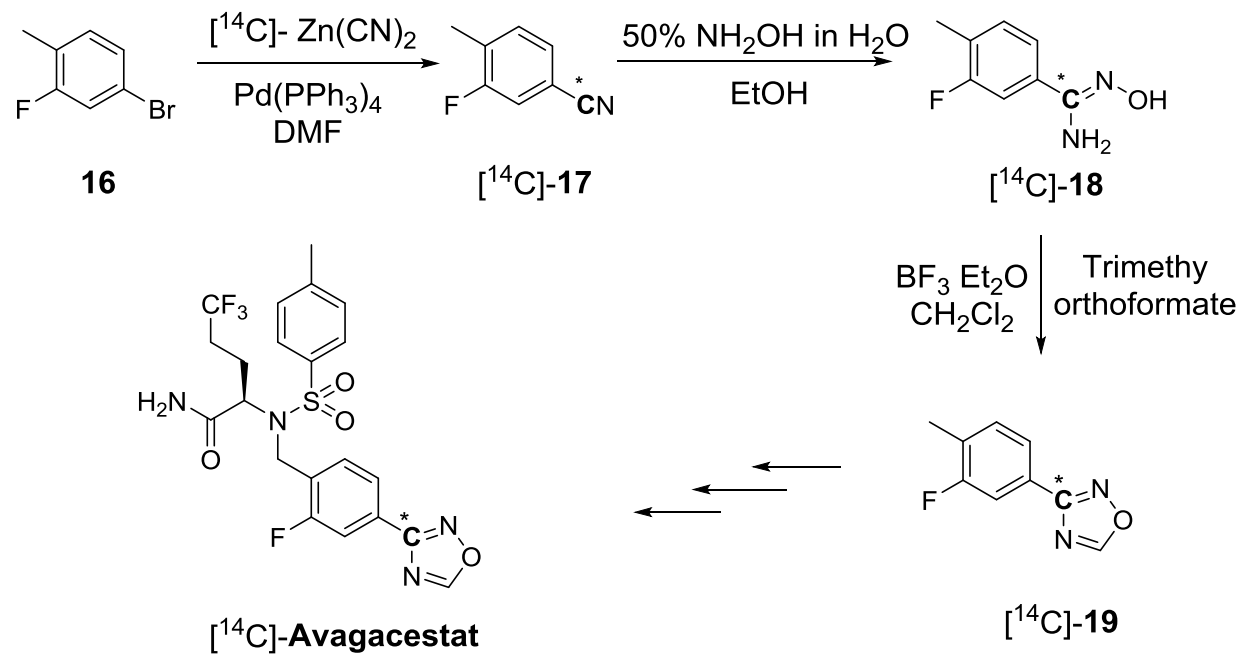

SCHEME 9 Synthesis of carbon-14 labeled Avagacestat.

The 1,2,4-oxadiazole core is found as well in compound $\left[{ }^{14} \mathrm{C}\right]-\mathbf{2 4}$, known as BI665915, a novel 5-lipooxigenase (FLAP) inhibitor developed in 2015 by Boehringer Ingelheim for the treatment of inflammatory diseases ${ }^{40}$. Palladium catalysed cyanation in presence of carbon-14 zinc cyanide allowed to obtain pyrazole $\left[{ }^{14} \mathrm{C}\right]-\mathbf{2 1}$ in $90 \%$. The carboxylic acid $\left[{ }^{14} \mathrm{C}\right]-\mathbf{2 2}$ was obtained by hydrolysis of derivative $\left[{ }^{14} \mathrm{C}\right]-\mathbf{2 1}$ using $\mathrm{NaOH}$, while the following step allowed to assemble the $\left[{ }^{14} \mathrm{C}\right]$-oxadiazole core of the drug $\left(\left[{ }^{14} \mathrm{C}\right]-23\right)$. The key cyclization was achieved through the activation of the carboxylic acid with carbonyldiimidazole (CDI) in presence of oxime 22a, three additional steps were required to deliver the desired $\left[{ }^{14} \mathrm{C}\right]-$ labeled oxadiazole with $84 \%$ yield and $20.5 \mathrm{mCi}$ produced (SCHEME 10).

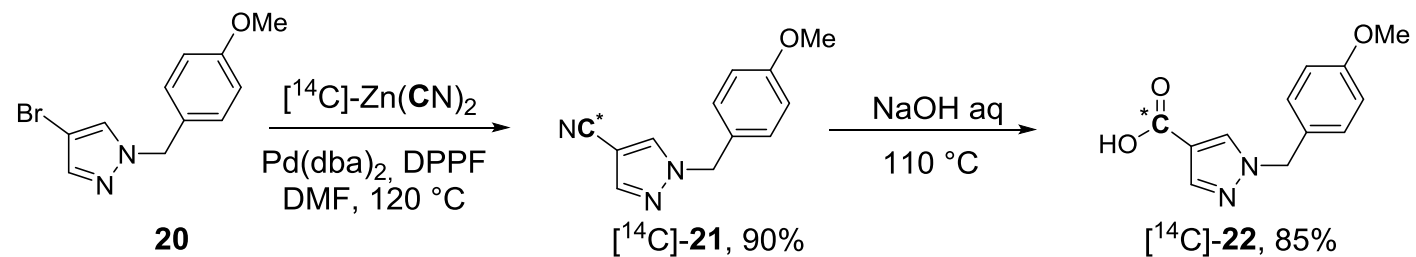<smiles>CN(C)C(=O)Cn1cc(-c2nc(C(c3ccc(-c4cnc(N)nc4)cc3)(C3CC3)C3CC3)no2)cn1</smiles>

$\left[{ }^{14} \mathrm{C}\right]-24,84 \%$<smiles>COc1ccc(Cn2cc(-c3nc(C4(c5ccc(Br)cc5)CC4)no3)cn2)cc1</smiles>

$\left[{ }^{14} \mathrm{C}\right]-23,89 \%$

SCHEME 10 Synthesis of carbon-14 BI665915. 
The imidazole core is another ubiquitous motif present in drugs. Easter and co-workers recently reported the access to $\left[{ }^{14} \mathrm{C}\right]$-Declatasvir, an intriguing example of symmetric imidazole containing $\operatorname{drug}^{41}$ (SCHEME 11).

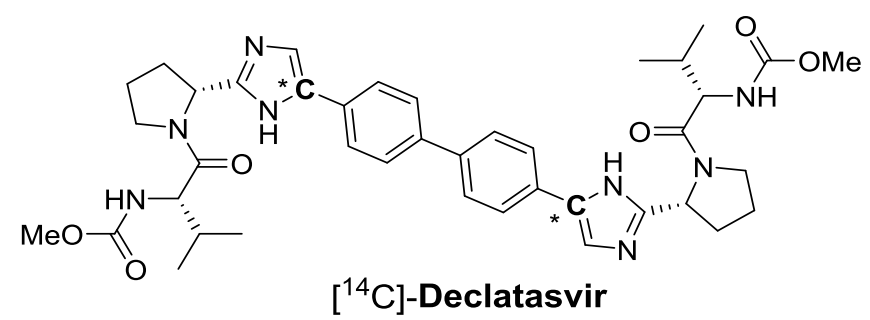

SCHEME 11 Structure of $\left[{ }^{14} \mathrm{C}\right]$-declatasvir.

This compound, commercialized by Bristol-Meyer-Squibb under the name of Daklinza, is an inhibitor of NS5A, a multifunctional protein involved in the replication of Hepatitis $\mathrm{C}$ virus. Its synthesis starts with the introduction of carbon-14 labeled $\mathrm{CN}$ on 4,4'-dibromodiphenyl (25), in refluxing DMF affording the diphenil-4,4'-dicarbonitrile $\left[{ }^{14} \mathrm{C}\right]-\mathbf{2 6}$ in $91 \%$ yield.

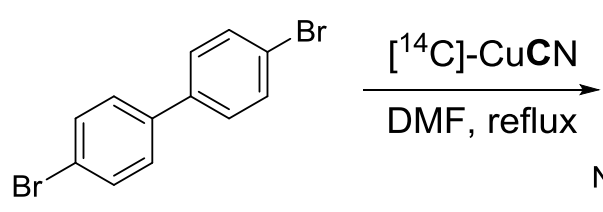

25<smiles>CC(=O)c1ccc(-c2ccc(C(=O)C(=O)c3ccc(Br)cc3)cc2)cc1</smiles><smiles>CC(C)(C)OC(=O)N1CCC[C@H]1c1ncc(-c2ccc(-c3ccc(-c4cnc([C@@H]5CCCN5C(=O)OC(C)(C)C)[nH]4)cc3)cc2)[nH]1</smiles>

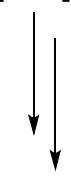<smiles>[Y][C@H]1CCC[C@H]1C(=O)OCC(=O)c1ccc(-c2ccc(C(=O)COC(=O)[C@@H]3CCCN3C(C)(C)C)cc2)cc1</smiles>

$\left[{ }^{14} \mathrm{C}\right]-28,74 \%$

SCHEME 12 Synthetic approach to symmetric imidazole derivative $\left[{ }^{14} \mathrm{C}\right]-29$.

The nitrile function was further converted to the corresponding diacetylbiphenyl $\left[{ }^{14} \mathrm{C}\right]-27$ using a tert-butyldimethylsilyl chloride-promoted nucleophilic addition of methyl magnesium chloride to the nitrile, in presence of a catalytic amount of copper bromide in $51 \%$ yield $^{42}$. Subsequent bromination and treatment with Boc-L-proline afforded the chiral precursor $\left[{ }^{14} \mathrm{C}\right]-$ 28, that was readily cyclized in presence of $\mathrm{NH}_{4} \mathrm{OAc}$ in refluxing toluene. Two additional steps yielded the desired $\left[{ }^{14} \mathrm{C}\right]$-Declatasvir (SCHEME 12).

In 2016, Shockravi et al. reported the synthesis of $\left[{ }^{14} \mathrm{C}\right]-33$, a selective COX-2 inhibitor belonging to the class of NSAID's (nonsteroidal-anti-inflammatory drugs). In this case, 
benzyl cyanide $\left[{ }^{14} \mathrm{C}\right]-\mathbf{3 1}$ was obtained in good yield from benzyl chloride $\mathbf{3 0}$ and the readily available $\left[{ }^{14} \mathrm{C}\right]-\mathrm{KCN}$. After three additional steps $\left[{ }^{14} \mathrm{C}\right]-31$ was elaborated into the $\alpha$-bromocarbonyl derivative $\left[{ }^{14} \mathrm{C}\right]-32^{43}$. In presence of sodium methoxide $\left[{ }^{14} \mathrm{C}\right]-32$ was further converted into the $\alpha$-hydroxy-carbonyl $\left[{ }^{14} \mathrm{C}\right]-32 a$, then the crude material was directly treated with $\mathrm{NH}_{4} \mathrm{SCN}$ in refluxing $n$-butanol, affording the labeled thiourea $\left[{ }^{14} \mathrm{C}\right]-33$ with $46 \%$ of overall yield (SCHEME 13).

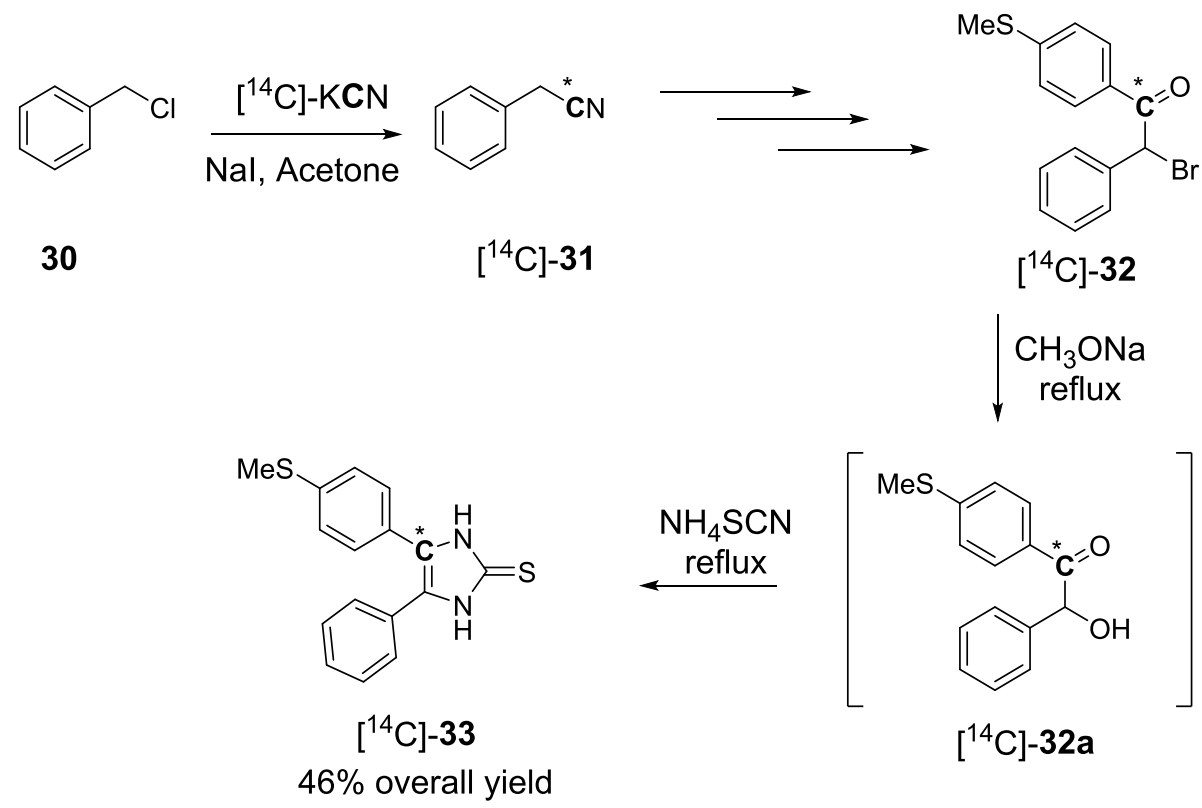

SCHEME 13 Synthesis of carbon-14 labeled thiourea derivative 33.

An expedient to label thiourea and thiopyrimidine heterocycles was described by Hickey et al. for the realization of $\left[{ }^{14} \mathrm{C}\right]-\mathrm{AZD}-5122$, a compound under evaluation as CXCR2 antagonist, a receptor involved in the accumulation and activation of neutrophils to the inflammations sites ${ }^{44}$. The isotope was introduced in to the pyridine ring using $\left[{ }^{14} \mathrm{C}\right]$-thiourea, which was condensed with diethyl malonate to afford the corresponding $\left[{ }^{14} \mathrm{C}\right]$-thiobarbituric acid salt $\left[{ }^{14} \mathrm{C}\right]-34$. In this way, the radioisotope was inserted in to a metabolically stable position, forming a six membered ring heterocycle with a masked thioguanidine. Further elaboration enabled the access to the desired $\left[{ }^{14} \mathrm{C}\right]-\mathrm{AZD}-5122$ in $67 \%$ yield with $18.9 \mathrm{mCi}$ produced (SCHEME 14).

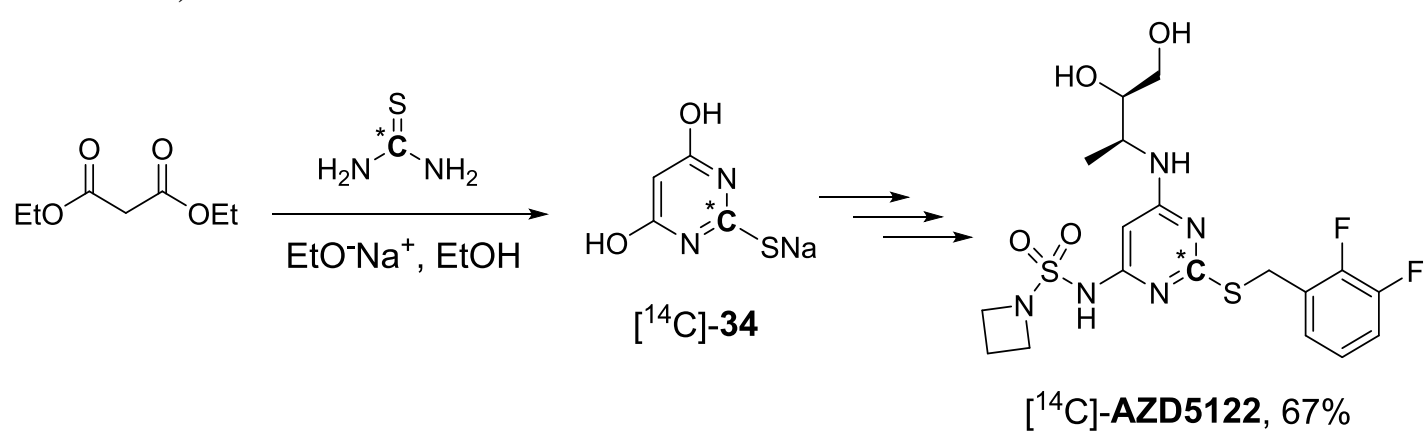

SCHEME 14 General approach to the synthesis of carbon-14 AZD5122.

In 2014, Elmore and co-workers at AstraZeneca reported a straightforward synthesis of $\left[{ }^{14} \mathrm{C}\right]-$ oxazole $\left[{ }^{14} \mathrm{C}\right]-38$. This spiro compound was required to investigate DMPK properties in a 
research program aiming towards the development of $\alpha 7$ agonists for the treatment of Alzheimer disease. $\left[{ }^{14} \mathrm{C}\right]$-nicotinic acid was prepared from 3-bromopyridine 35, treated first with $\mathrm{BuLi}$ at $-70{ }^{\circ} \mathrm{C}$ and further quenched with $\left[{ }^{14} \mathrm{C}^{\circ} \mathrm{CO}_{2}\right.$, with $58 \%$ of yield ${ }^{45}$. A peptide coupling between the elaborated amine 36 and $\left[{ }^{14} \mathrm{C}\right]$-nicotinic acid gave the corresponding amide $\left[{ }^{14} \mathrm{C}\right]-37$ in $40 \%$ yield. The key cyclization was performed heating the amide neat with the Eaton's reagent $\left(7.7 \mathrm{wt} \% \mathrm{P}_{2} \mathrm{O}_{5}\right.$ in $\left.\mathrm{MeSO}_{3} \mathrm{H}\right)$ at $130{ }^{\circ} \mathrm{C}$ affording the desired oxazole $\left[{ }^{14} \mathrm{C}\right]-$ 38 in $33 \%$ of yield and specific activity of $56 \mathrm{mCi} / \mathrm{mmol}$. Though the yields of the synthesis are moderate, the $\alpha 7$ agonist could be assembled and labelled in only three steps from the most fundamental building block, $\left[{ }^{14} \mathrm{C}\right] \mathrm{CO}_{2}$ (SCHEME 15).

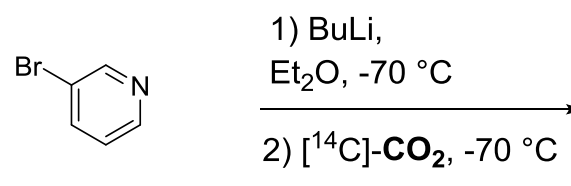<smiles>O=C(O)c1cccnc1</smiles>

$\left[{ }^{14} \mathrm{C}\right]-$ Nicotinic acid, $58 \%$

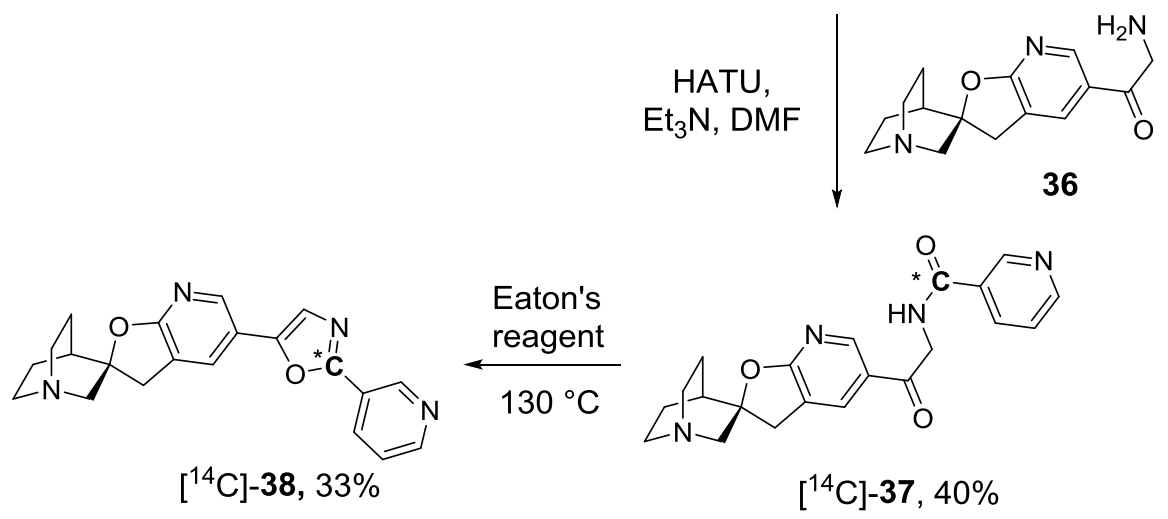

SCHEME 15 Synthesis of carbon-14 labeled $\alpha 7$ receptor agonist.

2-Iminothiolane, also known as Traut's Reagent ${ }^{46}$, is used as a tool to introduce a reactive thiol on a primary amine side chains of peptides. This lysine-thiolating agent has found applications as a linker in antibody-drug conjugates. (SCHEME 16) ${ }^{47}$. Wallace and coworkers at Bristol-Myers Squibb published a ${ }^{14} \mathrm{C}$-radiosynthesis of this reagent in 2015 . The isotope was introduced via $\mathrm{SN}_{2}$ reaction between $\left[{ }^{14} \mathrm{C}\right]-\mathrm{KCN}$ and 1-bromo-3-cloropropane affording the radiolabeled derivative $\left[{ }^{14} \mathrm{C}\right]-39$ with $82 \%$ of RCY. The reaction with thiourea delivered the $\left[{ }^{14} \mathrm{C}\right]$-isothiouronium hydrochloride salt $\left[{ }^{14} \mathrm{C}\right]-\mathbf{4 0}$, which was readily hydrolysed to compound $\left[{ }^{14} \mathrm{C}\right]-\mathbf{4 1}$. Under acidic conditions, $\left[{ }^{14} \mathrm{C}\right]-\mathbf{4 1}$ spontaneously cyclized to form $\left[{ }^{14} \mathrm{C}\right]$-2-iminothiolane $\left[{ }^{14} \mathrm{C}\right]-43$ with a RCY of $68 \%$ (SCHEME 16). 


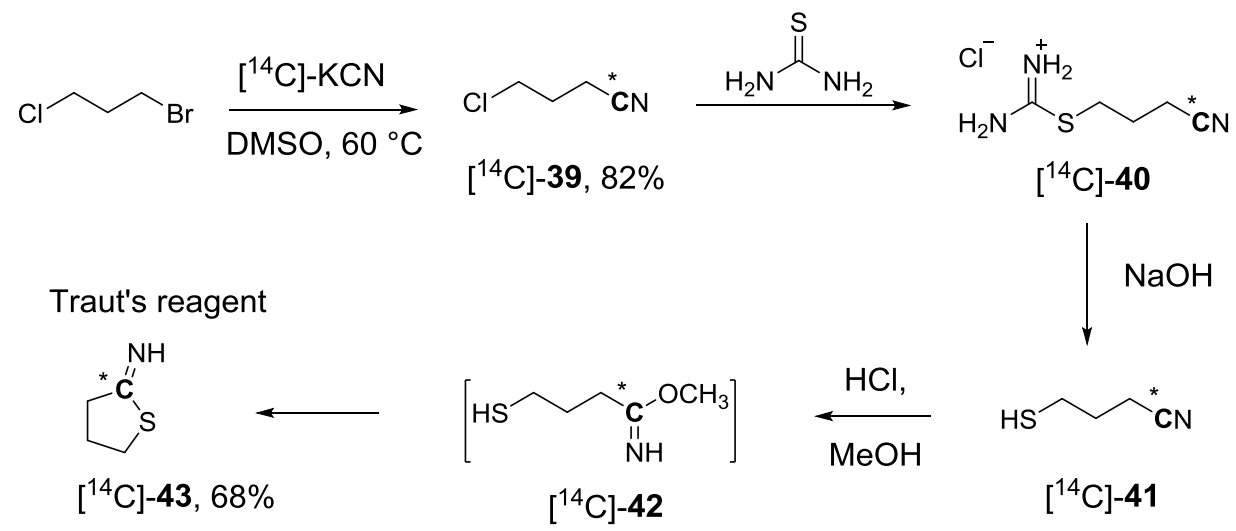

SCHEME 16 Synthesis of carbon-14 labeled Traut's reagent.

Deleobuvir is a non-nucleosidic selective NS5B polymerase inhibitor, marketed for the treatment of hepatitis $\mathrm{C}$ virus (HCV) infection. Its structure features two bicyclic heterocycles: a benzo-imidazole and an indole, connected to each other by a peculiar methylen-cyclobutan amide spacer. For its labeled version, Latli and co-workers decided to insert the radiocarbon tag on the benzoimidazole moiety ${ }^{48}$. The t-butyl cinnamate derivative 44 was reacted in presence of acid chloride $\left[{ }^{14} \mathrm{C}\right]-\mathbf{4 9}$ affording the key labelled intermediate $\left[{ }^{14} \mathrm{C}\right]-\mathbf{4 5}$, a benzo[d]imidazolone which was readily coupled with the other portion of the scaffold bearing the indole derivative (46). Further saponification of the butyl ester delivered the final $\left[{ }^{14} \mathrm{C}\right]$-Deleobuvir. The key cyclobutane amino acid $\left[{ }^{14} \mathrm{C}\right]-\mathbf{4 9}$ was obtained by means of a Bucherer-Bergs reaction in presence cyclobutanone $47,\left[{ }^{14} \mathrm{C}\right]-\mathrm{KCN}$ as radioisotope source and ammonium carbonate, to form the hydantoine intermediate $\left[{ }^{14} \mathrm{C}\right]-\mathbf{4 8}$ which was converted to compound $\left[{ }^{14} \mathrm{C}\right]-\mathbf{4 9}$ in two additional steps (SCHEME 17). 
a)

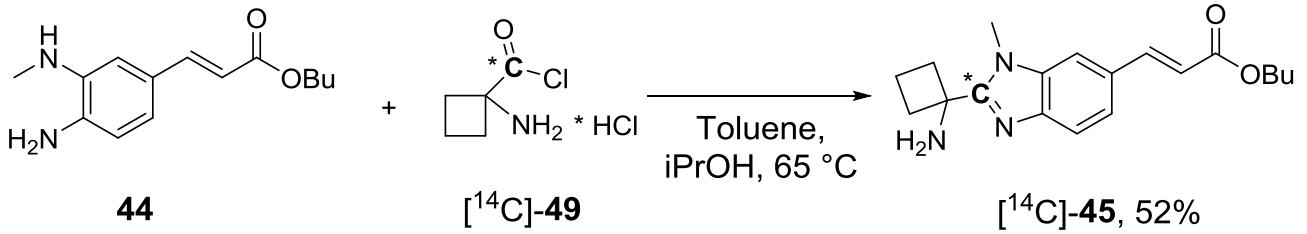

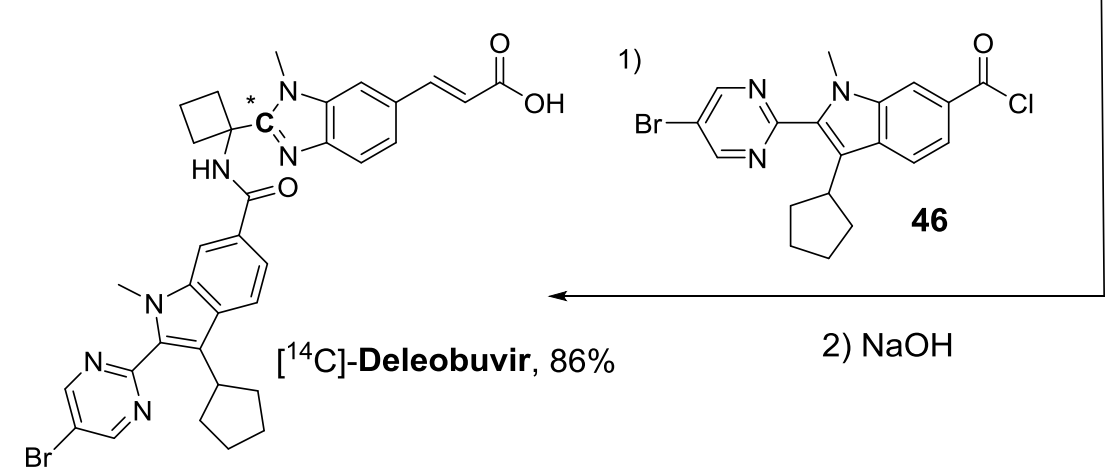

b)

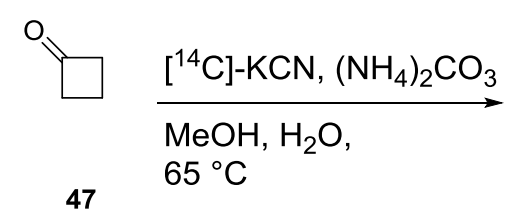<smiles>O=C1NC(=O)C2(CCC2)N1</smiles>

$\left[{ }^{14} \mathrm{C}\right]-48,55 \%$

SCHEME 17 a) Synthesis of carbon-14 labeled Deleobuvir; b) synthesis of carbon-14 labeled cyclobutane amino acid.

In 2015, the same authors described the carbon-14 radio synthesis of compound $\left[{ }^{14} \mathrm{C}\right]-\mathbf{5 5}$, a potent IкB Kinase- $\beta$ (IKK- $\beta$ ) inhibitor. Interestingly the thienopyridine heterocycle is largely present in different classed of compounds, with a broad recognized activity as HCV inhibitors, allosteric modulator of M4 muscarinic receptor and inhibitors of NMDA receptors ${ }^{49}$. For the realization of the bicycle, the authors started from the synthesis of a ${ }^{14} \mathrm{C}$ labeled pyridone using 2-cyanoacetamide $\left[{ }^{14} \mathrm{C}\right]-\mathbf{5 1}$ and a difluoroketoester 52. This Guareschi-Thorpe condensation in presence of DBU enabled the assembly of the corresponding tetrahydropyridine $\left[{ }^{14} \mathrm{C}\right]-\mathbf{5 3}$ which was further decorated to obtained compound $\left[{ }^{14} \mathrm{C}\right]-\mathbf{5 4}$ and cyclized under basic conditions to form the desired thienopyridine $\left[{ }^{14} \mathrm{C}\right]-\mathbf{5 5}$, ready utilized for ADME studies (SCHEME 18). 


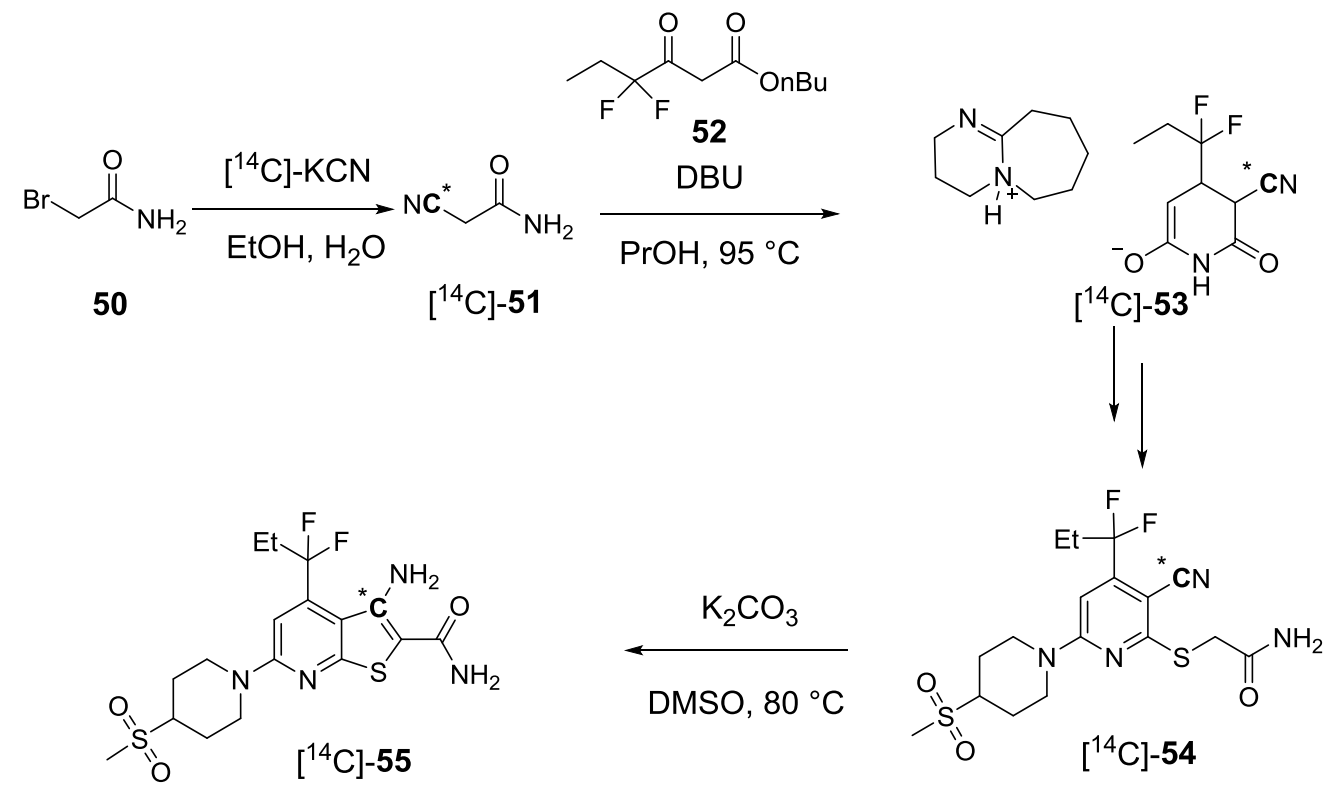

SCHEME 18 Synthesis of carbon-14 labeled IKK- $\beta$ inhibitor.

With the aim to develop a general approach to the synthesis of $\left[{ }^{14} \mathrm{C}\right]$-benzooxazoles and $\left[{ }^{14} \mathrm{C}\right]-$ benzothiazoles, Loreau and co-workers proposed a methodology based on the polarity inversion of the classic cyanating reagent $\mathrm{KCN}^{50}$. Electrophilic cyanide donor $\mathrm{N}$ cyanobenzotriazole $(\mathrm{BtCN})$ was generated in situ by adding $N$-chlorobenzotriazole $(\mathrm{Bt}-\mathrm{Cl})$ at $0{ }^{\circ} \mathrm{C}$ to $\left[{ }^{14} \mathrm{C}\right]-\mathrm{KCN}$. Labeled $\mathrm{BtCN}$ readily reacts with differently substituted 2 -aminophenols or 2-aminothiophenol, affording in one pot the corresponding labeled heterocycles. This methodology was applied for the radio-synthesis of $\left[{ }^{14} \mathrm{C}\right]-\mathbf{5 6}$, an advanced intermediate for the realization of different (R)-aryloxypropionic acid derivatives, a class of compound with herbicidal activity. $\left[{ }^{14} \mathrm{C}\right]-\mathbf{5 6}$ was obtained via amide coupling with $45 \% \mathrm{RCY}$ and $134.5 \mathrm{MBq}$ produced. It is worth mentioning, this one-pot protocol minimize the number of purifications required, limiting the generation of radioactive wastes and reducing the overall costs of the synthesis (SCHEME 19).
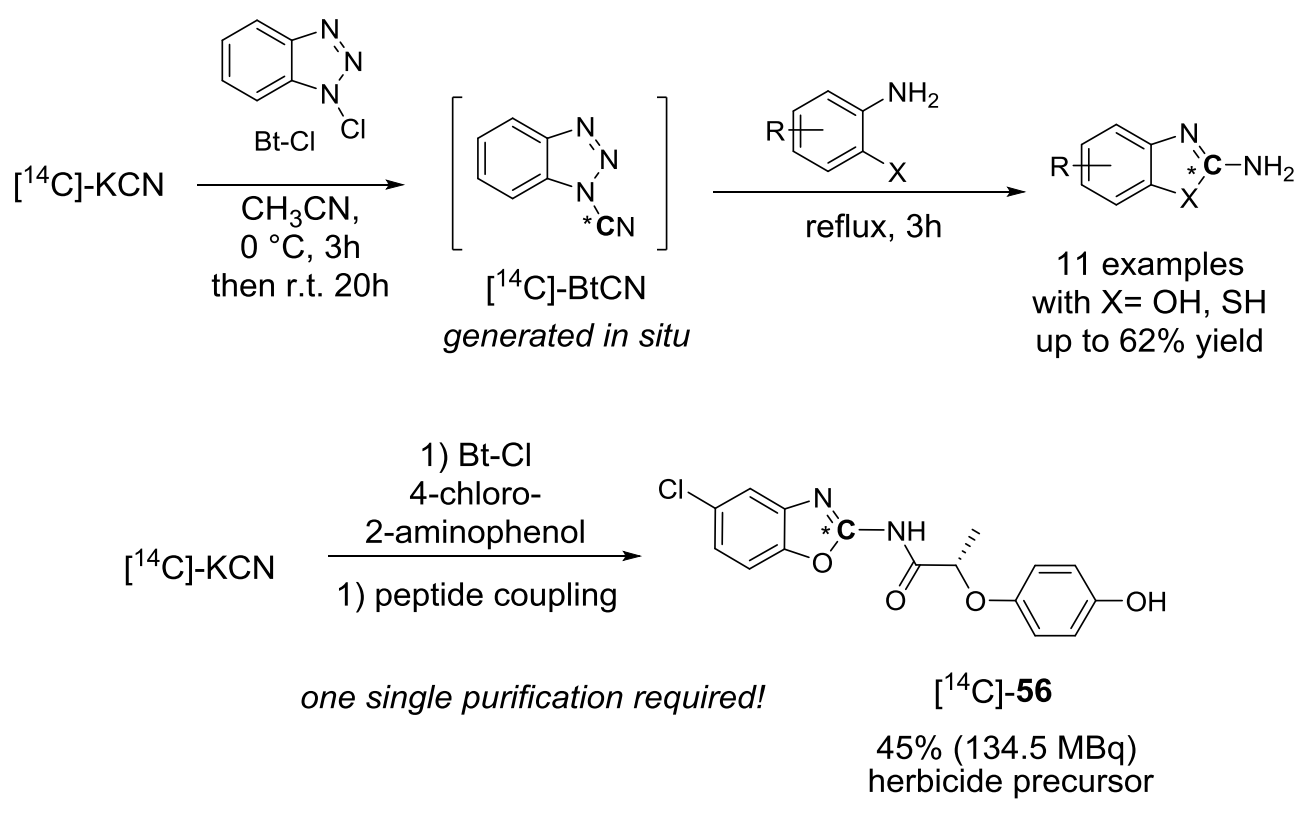
SCHEME 19 General procedure for the synthesis of carbon-14 labeled aryloxypropionic acid amides precursor.

In 2015, Latli et al. described the radiolabeling of pyrrole [2,3-c]pyridine from a $\left[{ }^{14} \mathrm{C}\right]$-alkyne derivative $\left[{ }^{14} \mathrm{C}\right]-\mathbf{5 7}$, which was cyclized during the last synthetic step to form the desired glucocorticoid receptor antagonist $\left[{ }^{14} \mathrm{C}\right]-\mathbf{5 9}{ }^{51}$. In this approach, the radioactivity was introduced via a regioselective ring opening of the chiral oxirane 56 by the advanced and doubly labeled precursor $\left[{ }^{14} \mathrm{C}\right]$-lithium (trimethylsilyl)acetylide. The silyl derivative was then treated with $\mathrm{NaOH}$ affording $\left[{ }^{14} \mathrm{C}\right]-57$. Consequently the $\left[{ }^{14} \mathrm{C}\right]$-labelled pyrrole[2,3-c]pyridine $\left[{ }^{14} \mathrm{C}\right]-\mathbf{5 9}$ was assembled from $\left[{ }^{14} \mathrm{C}\right] \mathbf{- 5 8}$, in a single deprotection and cyclization step, to form the final compound with no configurational changes (SCHEME 20).

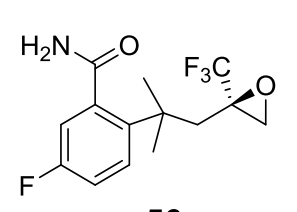

56
1) $\left[{ }^{14} \mathrm{C}\right]-\mathrm{TMS}^{-} \stackrel{*}{\mathbf{C}}=\stackrel{*}{\mathbf{C}}-\mathrm{Li}$

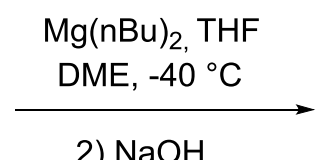

2) $\mathrm{NaOH}$

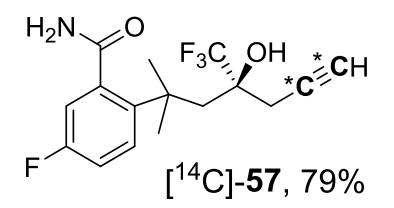

$\left[{ }^{14} \mathrm{C}\right]-\mathbf{5 7}, \mathbf{7 9} \%$

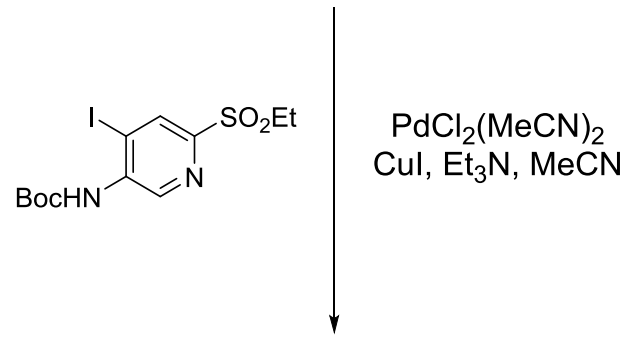

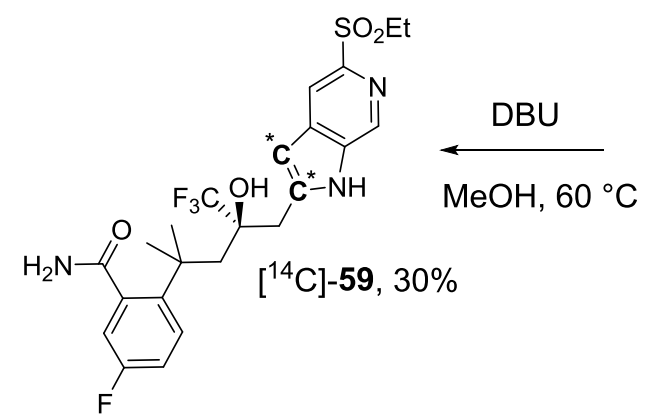

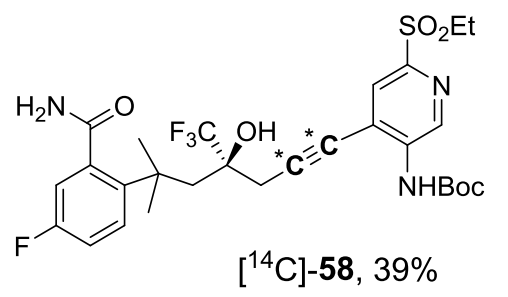

$\left[{ }^{14} \mathrm{C}\right]-58,39 \%$

SCHEME 20 Synthesis of carbon-14 labeled glucocorticoid receptor antagonist.

Recently, the labeling of the condensed heterocycle $\left[{ }^{14} \mathrm{C}\right]-\mathbf{6 1}$ was reported in a study by the Tran's group. This unconventional scaffold is present in a library of CB-1 antagonists, a class of compounds under investigation for the treatment of obesity ${ }^{52}$. The main core of the molecule, a triazolo [4,3-b] pyridazine carrying a carbonyl in position 2, was labeled quantitatively via a metal free carbonylation using $\left[{ }^{14} \mathrm{C}\right]-\mathrm{CDI}$. (SCHEME 21) 
<smiles>[R20]c1nnc(NN)c([R])c1[R]</smiles>

60

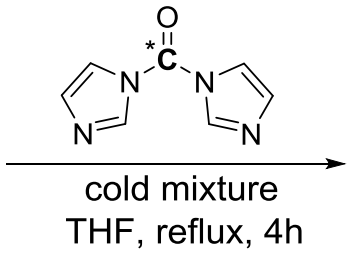

THF, reflux, $4 \mathrm{~h}$<smiles>[R]c1cnn2c(=O)[nH]nc2c1[R]</smiles>

$63 \%$ to $99 \%$

SCHEME 21 General synthetic route to carbon-14 labeled core of CB-1 receptor antagonist.

Omarigliptin, a compound currently in use for the treatment of diabetes mellitus type 2, was radiolabelled in 2016 by the Hesk group on the pyrazoles ring. Once more the use of hydrazine proved fundamental for the synthesis of condensed heterocycles ${ }^{53}$. In this case, the synthesis previously developed by the medicinal chemistry group was not viable and the radiochemists at Merk had to develop a whole new approach. The source of radioactivity chosen in this strategy was $\left[{ }^{14} \mathrm{C}\right]$-sodium formate, which was reacted in presence of biphenyl precursor 62 to give the corresponding formate $\left[{ }^{14} \mathrm{C}\right]-63$. A Claisen condensation with the enantio pure ketone $\left[{ }^{14} \mathrm{C}\right]-\mathbf{6 4}$ in presence of $\mathrm{tBuOK}$ afforded the corresponding vinylogous acid $\left[{ }^{14} \mathrm{C}\right]-65$ in $62 \%$ yield. Another condensation with hydrazine delivered the desired bicyclic key scaffold $\left(\left[{ }^{14} \mathrm{C}\right]-66\right)$ in one pot with the $94 \%$ of yield and $6.6 \mathrm{mCi}$ of material produced (SCHEME 22).
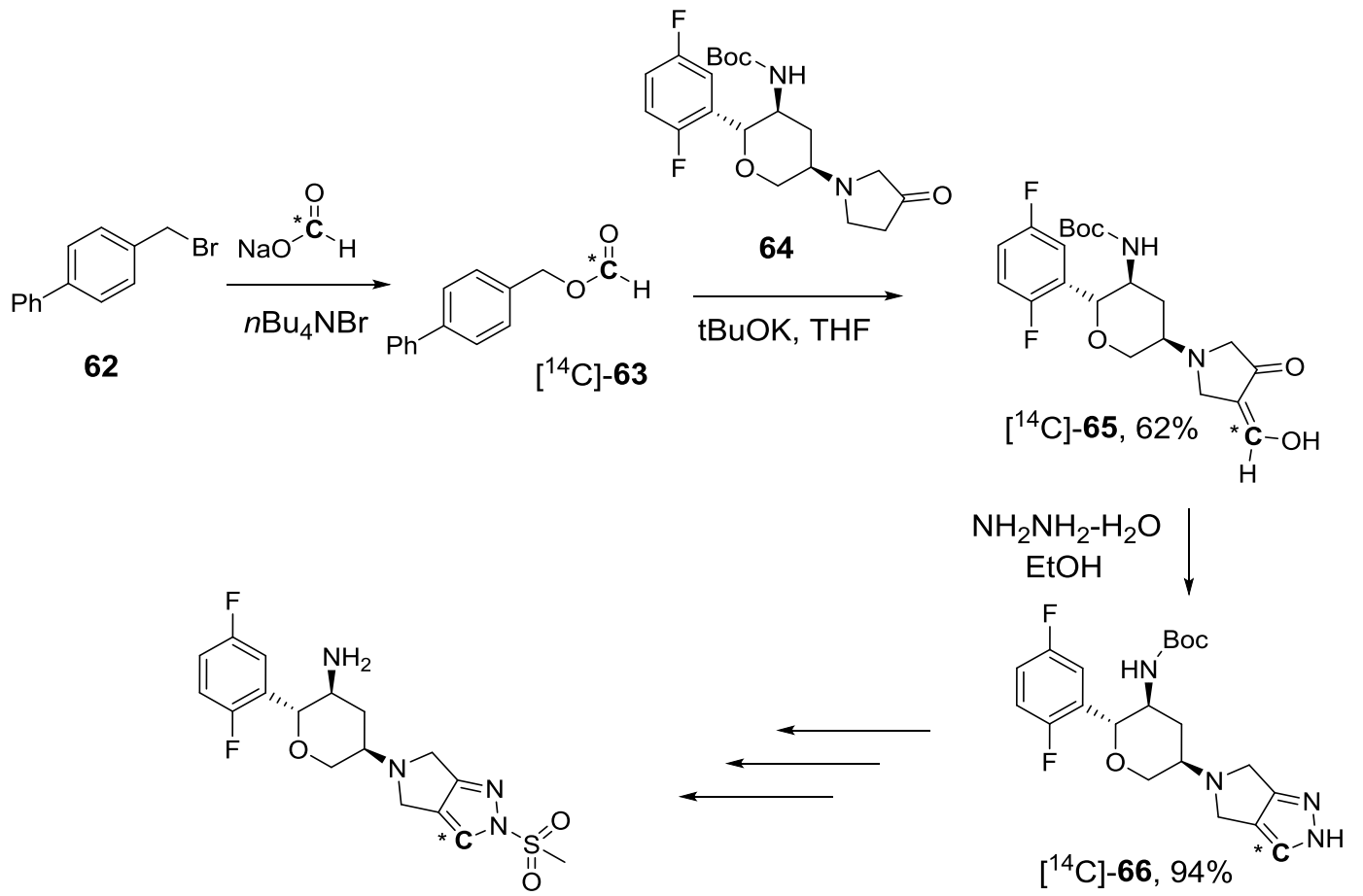

\section{$\left[{ }^{14} \mathrm{C}\right]$-Omarigliptin}

SCHEME 22 General synthesis of carbon-14 labeled Omarigliptin.

In 2014, chemists at Perkin Elmer realized a labelled version of Bergapten ${ }^{54}$, a compound belonging to furocoumarin family, bearing the ${ }^{14} \mathrm{C}$ atom in the pyrone ring, specifically at position 7. The previously reported synthesis of unlabelled Bergapten, starting from the aldehyde $\mathbf{6 8}$ and $\left[{ }^{14} \mathrm{C}\right]$-malonic acid, was not suitable to carbon labeling due to the required 
large excess of radioactive malonate. In addition, the following decarboxylation would have resulted in dilution of the specific activity and partial loss of the label. For those reasons, the authors decided to use a different strategy, based on the Wittig olefination of $\mathbf{6 8}$ in presence of the stabilized $\left[{ }^{14} \mathrm{C}\right]$-phosphonium ylide. The corresponding olefine was further cyclized at 220 ${ }^{\circ} \mathrm{C}$ in $\mathrm{N}, \mathrm{N}$-dimethyl aniline affording $\left[{ }^{14} \mathrm{C}\right]$-labelled Bergapten with $47 \%$ of RCY (SCHEME 23).

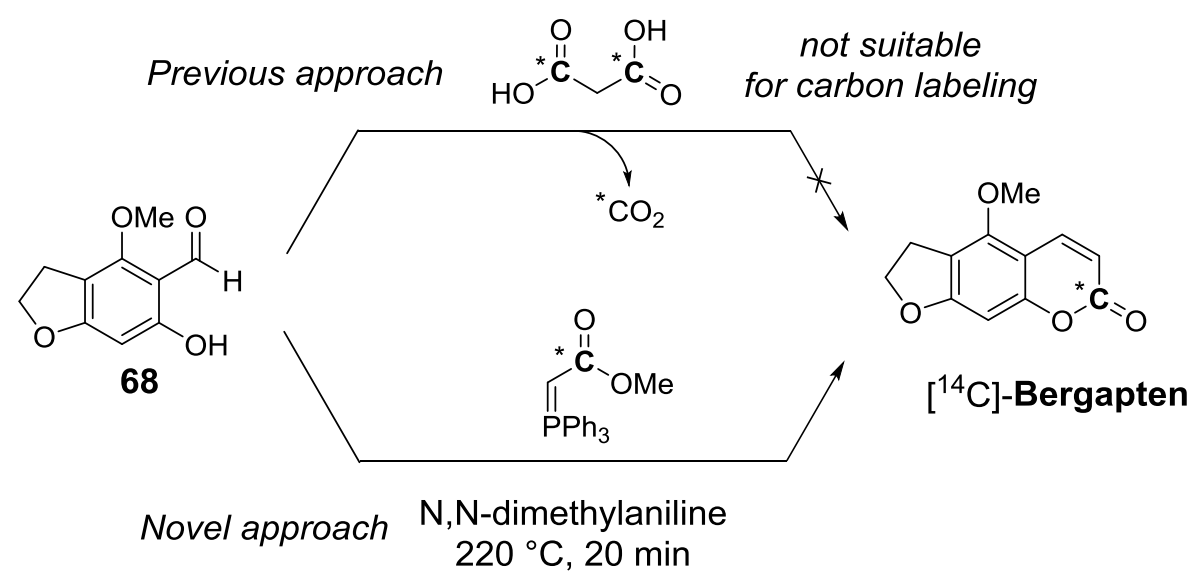

SCHEME 23 General approaches to the synthesis of carbon-14 labeled Bergapten.

Thioxanthen-9-one is a common scaffold present in several drugs with anti-parasitic activity, such as Lucanthone, a compound that exhibits anticolinergic activity in worms, in use for the treatment of schistosomiasis. In 2016, Javaheri et al. described a general route to such a tricyclic core ${ }^{55}$. The synthesis starts with the reaction between anthranilic acid $\left[{ }^{14} \mathrm{C}\right]-69$, readily obtained from $\left[{ }^{14} \mathrm{C}\right]$-potassium cyanide. Compound $\left[{ }^{14} \mathrm{C}\right]-69$ was solubilized in water and concentrated $\mathrm{HCl}$, then a solution of sodium nitrite was gradually added, at temperatures below $5{ }^{\circ} \mathrm{C}$. The intermediate labelled diazo derivative was added to a $\mathrm{Na}_{2} \mathrm{~S}_{2}$ solution. The resulting dimeric $\left[{ }^{14} \mathrm{C}\right]$-dithiosalicylic acid $\left[{ }^{14} \mathrm{C}\right]-\mathbf{7 0}$ was precipitated and subsequently refluxed in $\mathrm{AcOH}$ in presence of metal $\mathrm{Zn}$, to afford the monomer $\left[{ }^{14} \mathrm{C}\right]-\mathbf{7 1}$. Further condensation with $p$-fluorotoluene under acidic conditions afforded the $\left[{ }^{14} \mathrm{C}\right]$-labeled thioxanthene as mixture of regioisomers $\left[{ }^{14} \mathrm{C}\right]-\mathbf{7 2},\left[{ }^{14} \mathrm{C}\right]-\mathbf{7 3}$, in $66 \%$ combined yield (SCHEME 24).

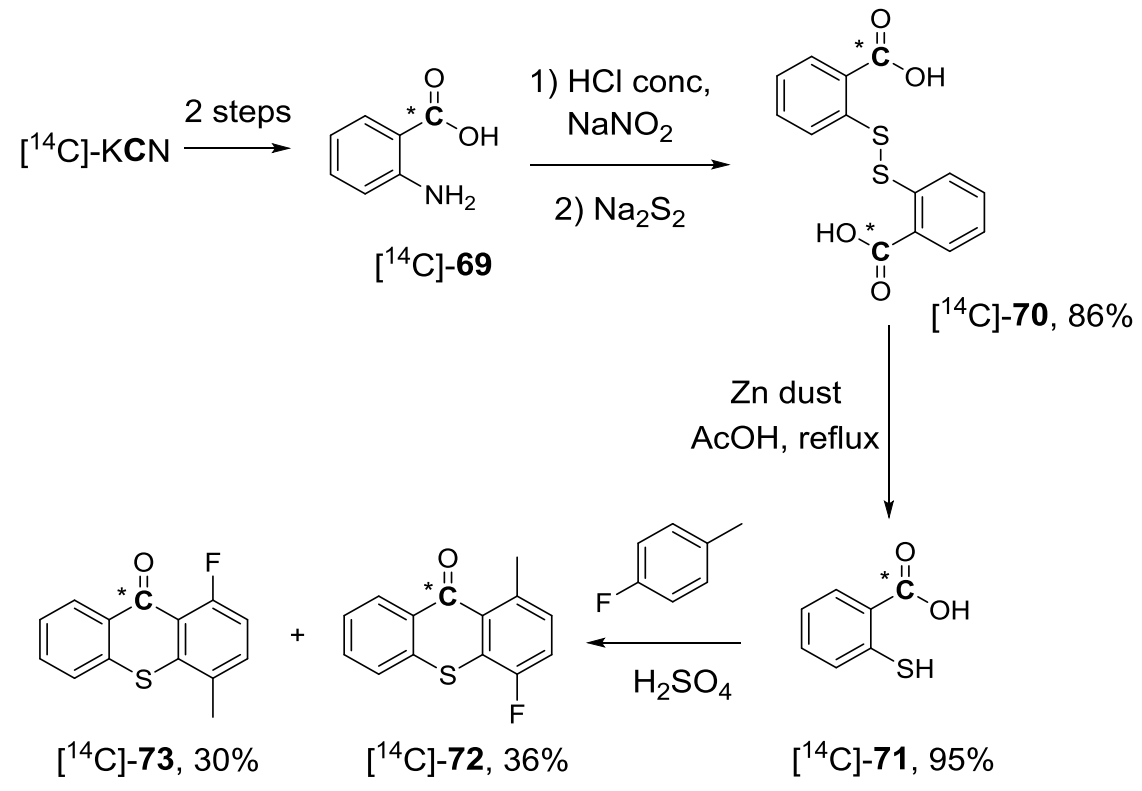


SCHEME 24 Synthesis of carbon-14 labeled thioxantene.

Tricyclic heterocycles are largely found in drugs with antipsychotic activity. Olanzapine, commercialized by Eli Lilly under the name of Zyprexa, is a representative example ${ }^{56}$. The carbon-14 radio synthesis of this particular second-generation neuroleptic agent starts from a nickel-catalysed cyanation of 3-bromo thiophene 74, according to a previously reported procedure $^{57}$. Subsequent nitro group reduction, followed by Buchwald-Hartwig cross coupling with 1-bromo-2-iodobenzene and $\mathrm{N}$-methyl piperazine addition to the nitrile, afforded the key precursor $\left[{ }^{14} \mathrm{C}\right]-76$. $\left[{ }^{14} \mathrm{C}\right]$-Olanzapine was finally obtained by an intramolecular metal catalysed cross coupling reaction in a $40 \%$ of isolated yield with $11.6 \mathrm{MBq}$ produced (SCHEME 25).

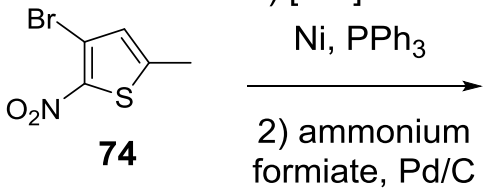

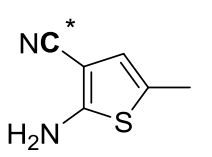

$\left[{ }^{14} \mathrm{C}\right]-75,36 \%$

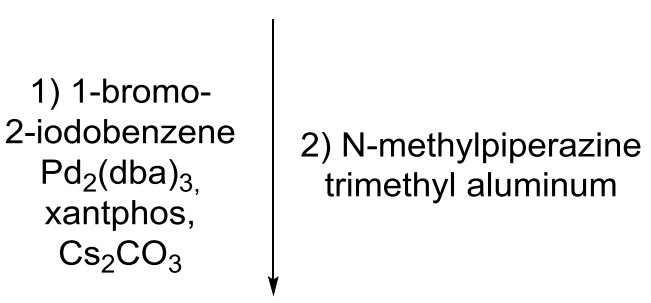

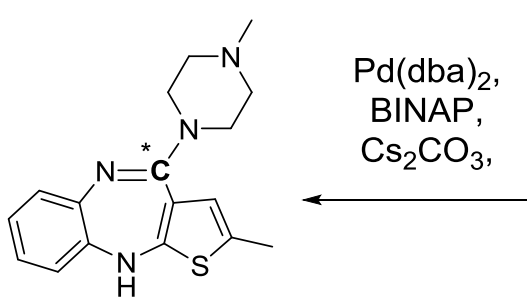

$\left[{ }^{14} \mathrm{C}\right]$-Olanzapine, $40 \%$

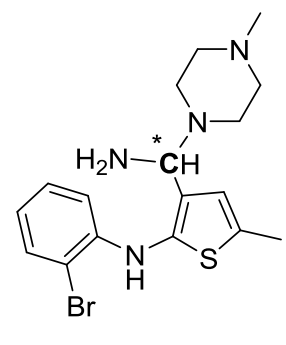

$\left[{ }^{14} \mathrm{C}\right]-76,47 \%$

SCHEME 25 Synthesis of carbon-14 labeled Olanzapine

As highlighted in this section, a very large variety of carbon-14 labeled heterocycles can be prepared. Unfortunately, most of the current approaches are lengthy, multi-step and demand massive efforts in terms of time and resources. Given the importance of this isotope and its implications in life science, future developments should favor the late and last stage carbon14 labeling of heterocycles using the simplest sources of the isotope $\left(* \mathrm{CO}_{2},{ }^{*} \mathrm{CO}\right.$ and $\left.* \mathrm{CN}\right)$.

\section{Synthesis of ${ }^{13} \mathrm{C}$ labelled heterocycles}

Carbon-13, a natural abundant stable isotope of carbon (1.1\%), is a valuable tracer in chemical, biological and environmental science. Common implications in mechanistic investigations in synthetic organic chemistry and its impact on NMR spectroscopy are well 
known ${ }^{58}$.The recent developments of dynamic nuclear polarization (DNP), which dramatically increases the sensitivity of the $\left[{ }^{13} \mathrm{C}\right]$-MRS experiment (>10,000 times) has allowed real-time imaging of several substrates and the metabolites formed from them in vivo ${ }^{59}$. In 2018 , La Clair has suggested a novel implication of this isotope for the encryption of materials, by adjusting the levels of $\left[{ }^{13} \mathrm{C}\right]$ at regiospecific atoms within a molecule, to generate a stableisotopically encoded signature ${ }^{60}$. It is worth mentioning that in stark contrast to the carbon-11 and carbon-14, the fundamental source of this isotope is carbon monoxide, as the current world production of ${ }^{13} \mathrm{C}$ is based on the cryogenic distillation of carbon monoxide ${ }^{61}$.

Over the last decade, tremendous efforts from the group of Prof. T. Skrydstrup in Denmark on the development of novel carbonylation strategies were made. In order to prevent the handling of poisonous $\mathrm{CO}$ gas, this group developed a novel two-chamber reactor, which allows the $e x$ situ generation of carbon monoxide (first chamber) which is subsequently delivered in the second chamber for its incorporation into complex organic molecules by means of metal catalyzed carbonylation reactions. The ex situ generation of $\mathrm{CO}$ was triggered by a palladium catalyzed decarbonylation of tertiary acid chloride (COgen) using palladium catalysis under mild conditions. This two chamber glassware system is known as Coware and is commercially available $^{62}$ (SCHEME 26). Besides Cogen, the same group reported the generation of carbon monoxide using silyl derivate ${ }^{63}$ starting directly from $\mathrm{CO}_{2} .{ }^{64} \mathrm{By}$ enabeling a safe handling of carbon monoxide, this technology had a massive impact on the field of metal catalyzed carbonylations. Subsequent elaboration of these carbonyl containing derivatives afforded a large variety of $\left[{ }^{13} \mathrm{C}\right]$-labeled heterocyles. It is worth noting that novel developments in the field of $\left[{ }^{13} \mathrm{C}\right]$-carbonylation can be highly inspiring and relevant for carbon- $14^{65}$.

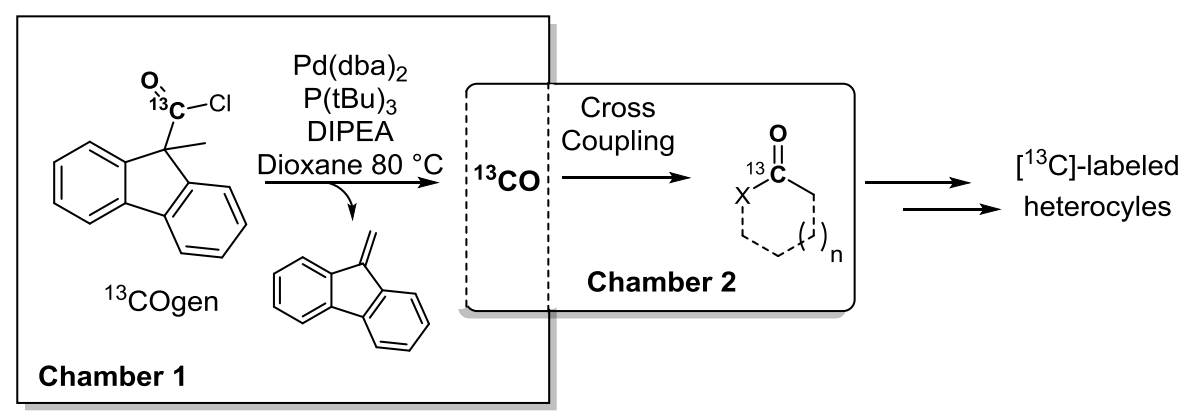

SCHEME 26 General formation of CO inside Cogen.

Palladium catalyzed intramolecular aminocarbonylation was shown to be a powerful tool for the direct labeling of heterocycles. Lactame $\left[{ }^{13} \mathrm{C}\right]-78$ was successfully obtained in $75 \%$ yield while the seven membered dibenzoxazepine ring $\left[{ }^{13} \mathrm{C}\right]-80$ could be isolated in $80 \%$ yield. Compound $\left[{ }^{13} \mathrm{C}\right]-\mathbf{7 8}$ is a precursor of Loxapine, an antipsychotic, used primarily in the treatment of schizophrenia (SCHEME 27a). ${ }^{62}$ 
a)

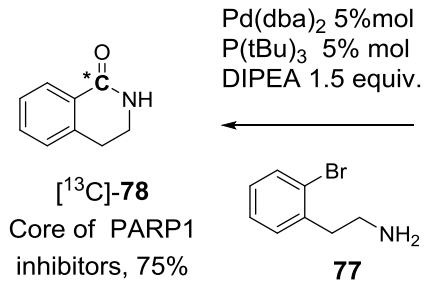

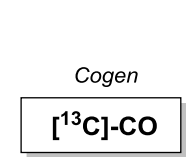

$\mathrm{Pd}(\mathrm{dba})_{2} 5 \% \mathrm{mo}$ $\mathrm{P}(\mathrm{tBu})_{3} 5 \% \mathrm{~mol}$ DIPEA 1.5 equiv.

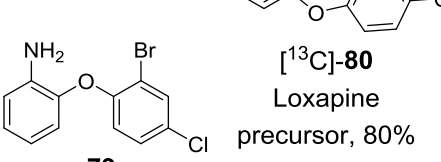

79

b)

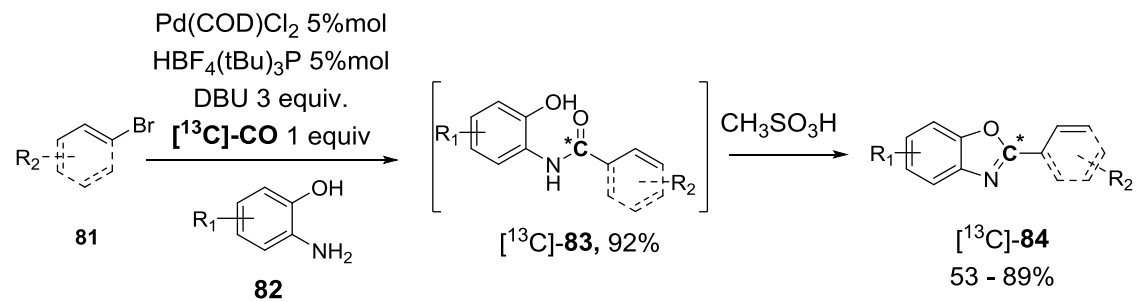

$\mathrm{Pd}(\mathrm{COD}) \mathrm{Cl}_{2} 5 \% \mathrm{~mol}$ $\mathrm{HBF}_{4}(\mathrm{tBu})_{3} \mathrm{P} 5 \% \mathrm{~mol}$<smiles>CNc1ccc(/C=C/c2nc3ccc(OCCF)cc3o2)cc1</smiles>
85 86

$\left[{ }^{13} \mathrm{C}\right]-\mathrm{BF}-168=74 \%$ (senile plaque binder)

$\mathrm{Pd}\left(\mathrm{tBu}_{3} \mathrm{P}\right)_{2} 5 \% \mathrm{~mol}$ $\mathrm{Bu}_{4} \mathrm{NCl} 1$ equiv

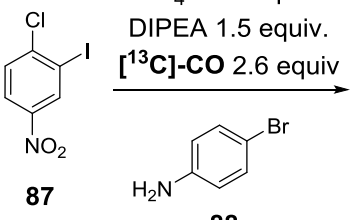

88

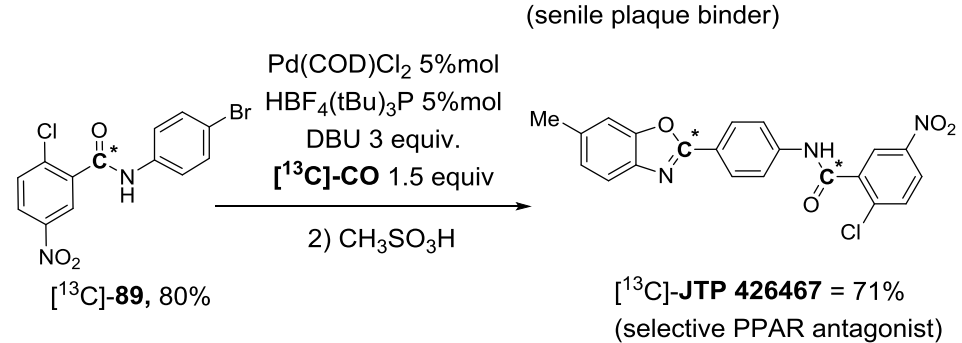

SCHEME 27 a) Intramolecular aminocarbonylation forming six and seven member ring; b) approach to benzoxazoles via aminocarbonylation and acidic ring closure.

A few years later, the same group published a sequential one-pot protocol for the synthesis of functionalized benzoxazoles (SCHEME 27b) ${ }^{66}$. Aminocarbonylation of aryl and vinyl bromides (81) with 2-aminophenols (82) followed by an acid mediated ring closure generated the benzoxazole heterocycles 84. The methodology displays a broad substrate scope and generally good yields. This carbonylative protocol was successfully applied to the synthesis of a potential Alzheimer's plaque binder $\left[{ }^{13} \mathrm{C}\right]-\mathbf{B F}-168$ and $\left[{ }^{13} \mathrm{C}\right]-\mathbf{J T P 4 2 6 4 6 7}$, a selective PPAR antagonist. The synthesis of this last compound includes also a site-specific double incorporation of $\left[{ }^{13} \mathrm{C}\right]$-carbon monoxide.

In 2011, the same authors reported a carbonylative Heck reaction between aryl iodides (90) and styrene derivatives (91) that efficiently delivered $\alpha, \beta$-unsaturated ketone $\left(\left[{ }^{13} \mathrm{C}\right]-\mathbf{9 2}\right)$. Interestingly, compound $\left[{ }^{13} \mathrm{C}\right]-\mathbf{9 2}$ was directly converted under acidic conditions into the corresponding indanone $\left[{ }^{13} \mathrm{C}\right]-93$ in $74 \%$ yield (SCHEME 28) ${ }^{67}$. 


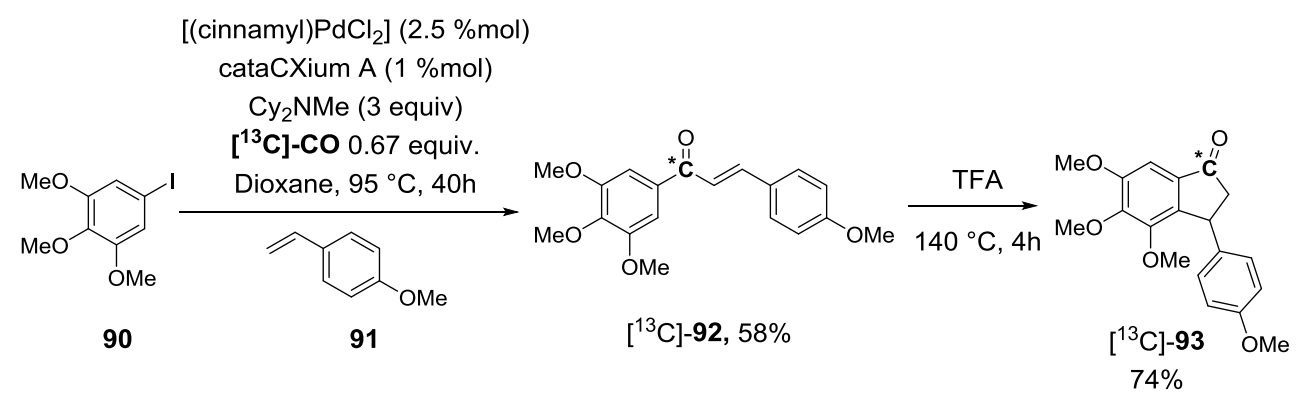

SCHEME 28 Approach to Indanone scaffold via carbonylative Heck reaction.

The subsequent year, the group of Skrydstrup disclosed the formation of 1,3-diketones through palladium-catalyzed carbonylative $\alpha$-arylation of ketones with aryl iodides. It is well known that 1,3-diketones are privileged precursors to access a large variety of heterocycles ${ }^{68}$. The authors explored the possibility of using their novel transformation for the isotopic labeling of three fundamental heterocyclic scaffolds largely found in medicinal chemistry: pyrazole, isoxazole and flavone. 2-iodophenols 94a-b were carbonylated in excellent yields using carbon-13 labeled COgen. Subsequent hydrolysis of the methoxymethyl ether $\left[{ }^{13} \mathrm{C}\right]-\mathbf{9 6 a}$ and cyclization formed the flavone $\left[{ }^{13} \mathrm{C}\right]-97$ in quantitative yield. Derivative $\left[{ }^{13} \mathrm{C}\right]-96 a$ was converted into the corresponding pyrazoles $\left[{ }^{13} \mathrm{C}\right]-\mathbf{9 8}$ and isoxazole $\left[{ }^{13} \mathrm{C}\right]-\mathbf{9 9}$, under standard conditions in presence of hydrazine and hydroxylamine respectively (SCHEME 29). These examples highlighted the effectiveness of carbonylative cross coupling for the late stage carbon labeling of relevant heterocycles, which are commonly found in drugs and natural products. It is worth noting that such scaffolds were obtained in only two steps using $\left[{ }^{13} \mathrm{C}\right]-$ COgen.

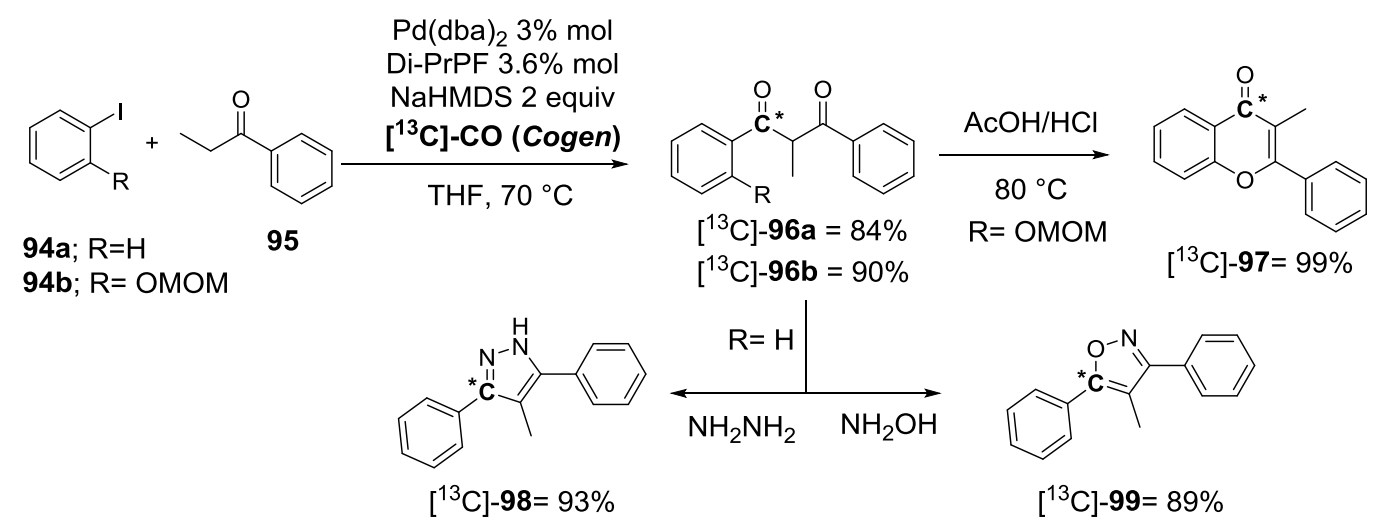

SCHEME 29 Sythesis of drug-like heterocycles via palladium catalyzed carbonylation.

Another successful example of the two chamber COgen system in the context of heterocycle labeling was reported in 2014 by means of a palladium-catalyzed carbonylative coupling of (2-aza-aryl)methyl anion equivalents with (hetero)aryl bromides. Under the optimized reaction conditions, (2-pyridyl)acetone (100) was converted into of aryl-2-(2pyridyl)ethanone in one single operation. Derivative $\left[{ }^{13} \mathrm{C}\right]-\mathbf{1 0 2}$ was isolated $85 \%$ yield (SCHEME 30 $)^{69}$. Benzylic bromination followed by reaction with thiourea resulted in the formation of the disubstituted thiazolamine $\left[{ }^{13} \mathrm{C}\right]-\mathbf{1 0 3}$ in a $58 \%$ yield. The reaction of $\left[{ }^{13} \mathrm{C}\right]-$ 
102 with hydroxylamine followed by sequential treatment with trifluoroacetic anhydride and iron(II) chloride delivered the isotopically labeled pyrazolopyridine $\left[{ }^{13} \mathrm{C}\right]-104$ in a $46 \%$ yield.

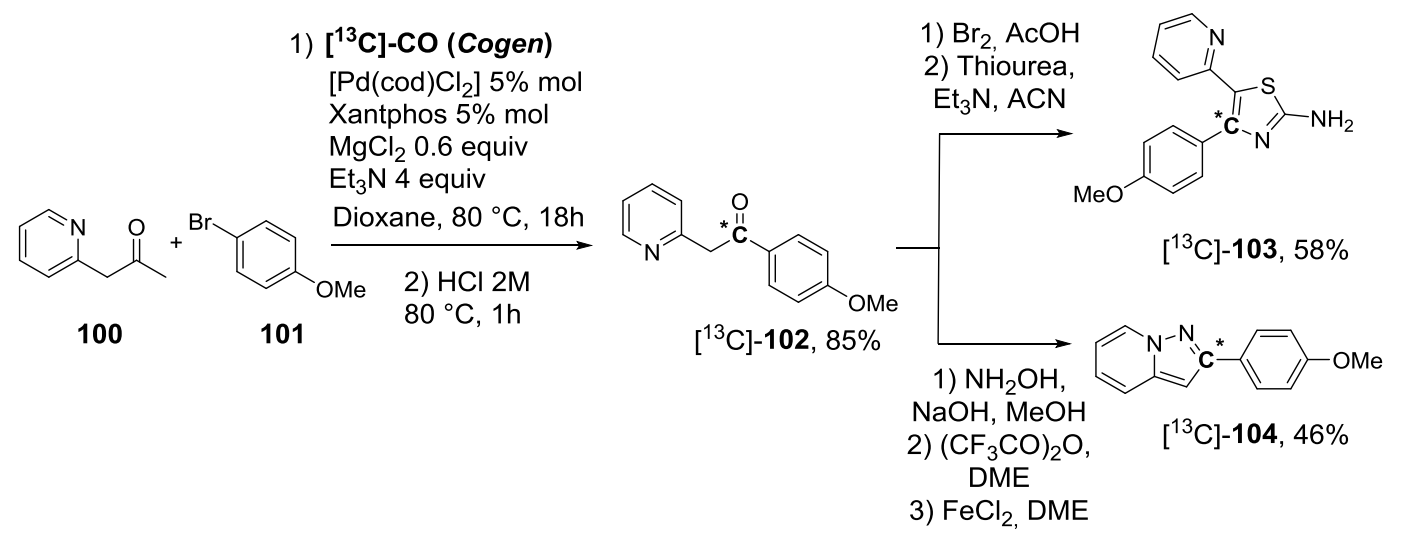

SCHEME 30 Carbon-13 labeling of thiazolamine and pyrazolopyridine derivatives.

In the same year, the Skrydstrup group expanded even further the scope of heterocycles with benzothiophene, ${ }^{70} 1,2,4$ - and 1,3,4-oxadiazole derivates ${ }^{71}$. In the first report, the aryl bromide 105 was coupled with 2- mercaptobenzophenones 106 via palladium carbonylation in order to obtain the thioester $\left[{ }^{13} \mathrm{C}\right]-\mathbf{1 0 7}$ with $70 \%$ yield; then under McMurry coupling conditions the thioester was cyclized to obtain $\left[{ }^{13} \mathrm{C}\right]-\mathbf{1 0 8}$ in good yield, as depicted in SCHEME 31.

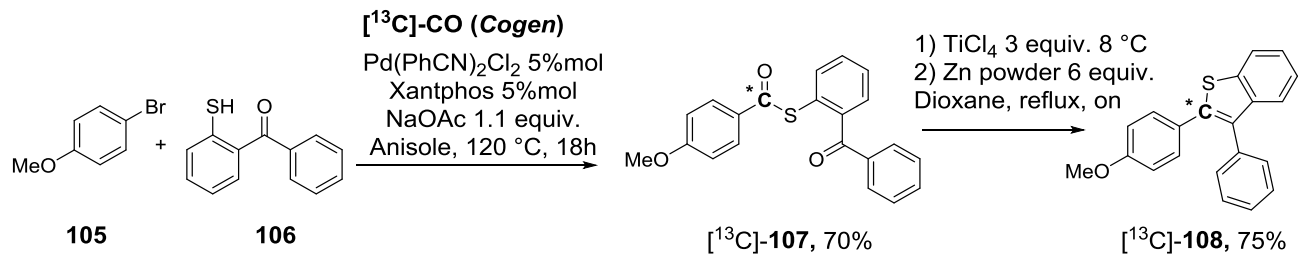

SCHEME 31 Synthesis of benzothiophene derivate via palladium carbonylation and McMurry coupling.

Another remarkable application was described in 2014 on the formation of substituited 1,3,4oxadiazoles. In the two step procedure depicted in SCHEME 32a, a variety of (het)aryl bromides (109) were coupled with hydrazide derivates (110) under the carbonylating condition and the cyclization were performed in one pot with good to excellent yields. Moreover, another regioisomer of this scaffold could be labeled, the 1,2,4-oxadiazole, leading to the pharmaceutical relevant compound $\left[{ }^{13} \mathrm{C}\right]$-Ataluren, a drug used for the treatment of Duchenne muscular dystrophy. In SCHEME 32b is depicted the synthesis of $\left[{ }^{13} \mathrm{C}\right]$-Ataluren, obtained with a coupling between the amidoxide 113 and fluoro aryl bromide $\mathbf{1 1 2}$. 
a)

1) $\left[{ }^{13} \mathrm{C}\right]-\mathrm{CO}$ (Cogen)

$\mathrm{Pd}(\mathrm{dba})_{2} 1 \% \mathrm{~mol}$

政

109

22 equiv.

Dioxane, $95^{\circ} \mathrm{C}, 16 \mathrm{~h}$

$\left[{ }^{13} \mathrm{C}\right]-111$

from 63 to $99 \%$

1) $\left[{ }^{13} \mathrm{C}\right]-\mathrm{Co}($ Cogen)

b)

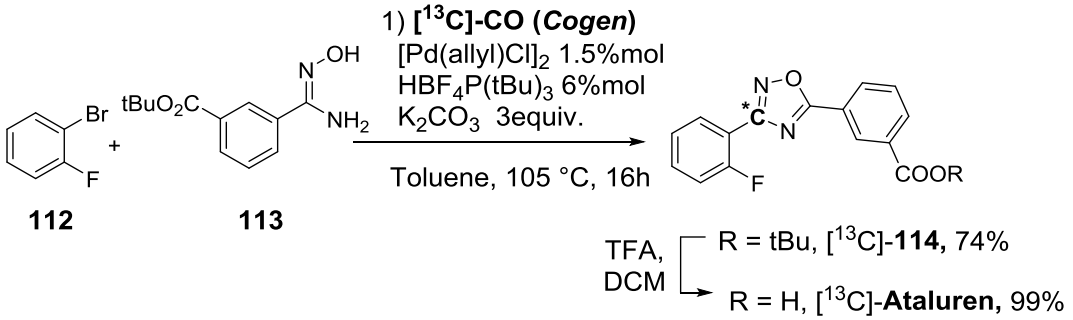

SCHEME 32 a) formation of subsostituited 1,3,4-oxadiazole; b) Synthetic approach to $\left[{ }^{13} \mathrm{C}\right]-$ Ataluren, 1,2,4-oxadiazole.

Very recently, Skrydstrup reported the synthesis of THK-523, a pharmaceutically relevant Tau binder (SCHEME 33) ${ }^{72}$. This compound was obtained through a palladium catalyzed carbonylative Sonogashira coupling $\left(\left[{ }^{13} \mathrm{C}\right]-117,72 \%\right)$ and a subsequent reductive cyclization step with hydrogen or deuterium gas $\left(\left[{ }^{13} \mathrm{C}\right]-\mathbf{T H K}-\mathbf{5 2 3}, 87 \%\right)$. Though this is not a direct late stage carbon labeling, however this and the previous methodology display an high potential for the carbon labeling of a large number keys heterocycles in natural products and drug-like molecules.

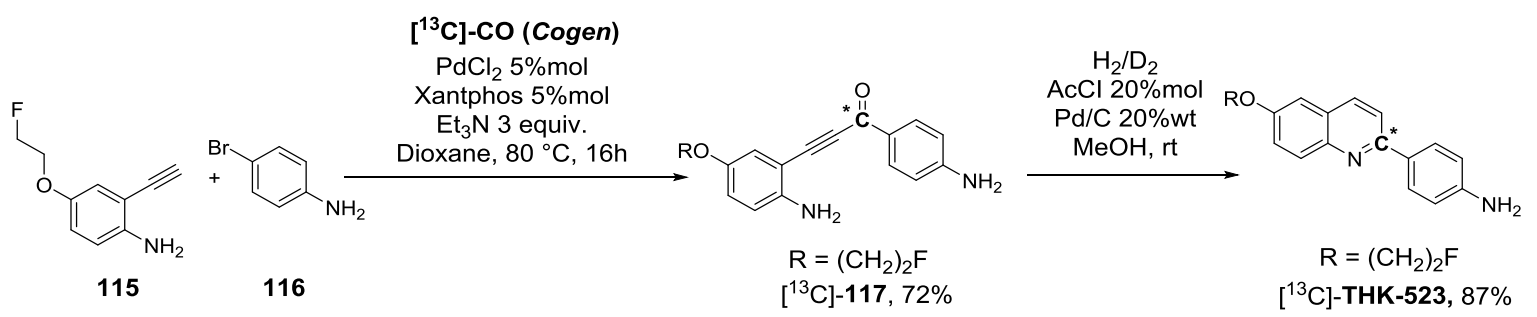

SCHEME 33 Synthesis of pharmaceutically relevant Tau binder $\left[{ }^{13} \mathrm{C}\right]-\mathrm{THK}-523$.

Metal catalyzed carbonylative cross coupling reactions are very effective tools to access a large number of heterocycles. This section clearly highlights the potential of this reaction. In principle, this chemistry could be fully adapted to carbon-14 labeling as well. To our surprise, for the moment it has not been the case. One possible explanation is that ${ }^{14} \mathrm{C}$-Cogen requires a three steps process to generate $\left[{ }^{14} \mathrm{C}\right] \mathrm{CO}$ and might discourage its popularization in the radiochemical community. Transformations leading to the formation of labeled $\mathrm{CO}$ directly from $\mathrm{CO}_{2}$ might be beneficial to broaden its utilization in radiochemistry.

\section{Conclusions and outlook}

In this review, we have presented on overall view of the recent advances in the context of carbon isotope labeling of pharmaceutically and agrochemically relevant heterocycles. This exciting field is nowadays very rich and vibrant as highlighted by the variety of solutions reported in the last five to ten years. Despite such great number of approaches, as a matter of 
fact, this topic is today still very challenging and the available synthetic solutions are often substrate specific and lack of generality. Of course, one major limitation is related to the different specifications of carbon isotopes and general solutions have so far not been reported. From an ideal point of view, the development of new methodologies utilizing the most simple labeled starting materials $\left({ }^{*} \mathrm{CO}_{2},{ }^{*} \mathrm{CO}, \mathrm{K} * \mathrm{CN}\right)$, short reaction times and late or last stage labeling should be favored in the future. When possible, these guidelines should be kept in mind. We are very confident that the carbon isotope labeling can provide a whole range of innovation in the next decades.

\section{Notes}

The authors declare no conflicts of interest

\section{Acknowledgments}

This project has received funding from the European Union's Horizon 2020 research and innovation programme under the Marie Sklodowska-Curie grant agreement №675071.

\section{References}

\footnotetext{
${ }^{1}$ a) Vitaku E, Smith DT, Njardarson T. Analysis of the Structural Diversity, Substitution Patterns, and Frequency of Nitrogen Heterocycles among U.S. FDA Approved Pharmaceuticals. J. Med. Chem. 2014;57:10257-10274; b) Baumann M, Baxendale IR. An overview of the synthetic routes to the best selling drugs containing 6-membered heterocycles Beilstein J. Org. Chem. 2013;9:2265-2319; c) Taylor AP, Robinson PR, Fobian YM, Blakemore DC, Jones LH, Fadeyi O, Modern advances in heterocyclic chemistry in drug discovery Org. Biomol. Chem. 2016;14:6611-6637.

${ }^{2}$ Gomtsyan A, Heterocyles in drugs and drugs discovery. Chemistry of Heterocyclic Compounds 2012;48:7-10.

${ }^{3}$ A. Mullard. 2017 FDA drug approvals Nat. Rev. Drug Discov. 2018, 17, 81.

${ }^{4}$ Miller PW, Long NJ, Vilar R, Gee AD. Synthesis of [11C], [18F], [15O], and [13N] radiolabels for positron emission tomography Angew. Chem. Int. Ed. 2008;47:8998-9033.

${ }^{5}$ Rotstein BH, Liang SH, Placzek MS, Hooker JM, Gee AD, Dolle F, Wilson AA, Vasdev N. [11C]CO bonds made easily for positron emission tomography radiopharmaceuticals. Chemical Society Reviews 2016;45:4708-4726.

${ }^{6}$ Dahl K, Halldin C,Schou M. New methodologies for the preparation of carbon-11 labeled radiopharmaceuticals Clinical and Translational Imaging 2017;5:275-289.

${ }^{7}$ Rotstein BH, Liang SH, Holland JP, Collier TL, Hooker JM, Wilson AA, Vasdev N; $[11 \mathrm{C}] \mathrm{CO}_{2}$ fixation: a renaissance in PET radiochemistry Chem. Commun. 2013;49:5621-5629.

$8 \mathrm{Tu}$ Z, Mach RH, C-11 Radiochemistry in Cancer Imaging Applications Current Topics in Medicinal Chemistry 2010;10:1060-1095.

${ }^{9}$ Kealey S, Gee A, Miller PW. Transition metal mediated $\left[{ }^{11} \mathrm{C}\right]$ carbonylation reactions: recent advances and applications. J Label Compd Radiopharm. 2014;57:195-201.

${ }^{10}$ Mane RS, Nordeman, P, Odell LR, Larhed M, Palladium-catalyzed carbonylative synthesis of N -cyanobenzamides from aryl iodides / bromides and cyanamide. Tetrahedron Lett. 2013;54:6912-6915.

${ }^{11} \mathrm{Wu}$ X, Sun S, Wang B, Cheng J. The Base-Promoted Annulation of 2-Hydrazinyl Pyridine and $\mathrm{CO}_{2}$ toward Triazolones. Adv. Synth. Catal. 2017;359:3855-3859.

${ }^{12}$ Rahman O. [11C]Carbon monoxide in labeling chemistry and positron emission tomography tracer development: scope and limitations. J. Label Compd. Radiopharm 2015;58:86-98.

${ }^{13}$ Schoenberg A, Bartoletti I, Heck RF. Palladium-Catalyzed Carboalkoxylation of Aryl, Benzyl, and Vinylic Halides. J. Org. Chem 1974;39:3318-3326.

${ }^{14}$ Garrou PE, Heck RF. The Mechanism of Carbonylation of Halo( bis ligand)organoplatinum( II), -palladium( II), and nickel( II) Complexes. J. Am. Chem. Soc. 1975;98:4115-4127.

${ }^{15}$ T. Kihlberg, B. Långström, Method and apparatus for productionand use of [11C]carbon monoxide in labeling synthesis. PCT Int.Appl. 2002, WO, 2002102711 A1.

${ }^{16}$ Kealey S, Miller PW, Long NJ, Plisson C, Martarello L, Gee AD. Copper(I) scorpionate complexes and their application in palladium-mediated [11C]carbonylation reactions, Chem. Commun, 2009;0:3696-3698.
} 
${ }^{17}$ Kealey S, Husbands SM, Bennacef I, Gee AD, Passchier J. Palladium-mediated oxidative carbonylation reactions for the synthesis of [11C]-radiolabelled ureas, J. Label Compd. Radiopharm 2014;57:202-208.

${ }^{18}$ Kealey S, Miller PW, Long NJ, Plisson C, Martarello L, Husbands SM, Gee AD Microfluidic reactions using [11C]carbon monoxide solutions for the synthesis of a positron emission tomography radiotracer Org. Biomol. Chem, 2011;9:3313-3319.

${ }^{19}$ E. Lallana, R. Riguera, E. Fernandez-Megia. Reliable and Efficient Procedures for the Conjugation of Biomolecules through Huisgen Azide-Alkyne Cycloadditions Angew. Chem. Int. Ed. 2011, 50, 8794-8804.

${ }^{20}$ Cornilleau T, Audrain H, Guillemet A, Hermange P, Fouquet E, General Last-Step Labeling of Biomolecule-Based Substrates by [12C],[13C], and [11C] Carbon Monoxide Org. Lett.,2015;17:2,354-357.

${ }^{21}$ Eriksson J, Hoek JVD, Windhorst AD. Transition metal mediated synthesis using [11C]CO at low pressure-a simplified method for [11C]-carbonylation. J. Label Compd. Radiopharm 2012;55:223-228.

${ }^{22}$ Song G, Wang WF, Li X, C-C, C-O and C-N bond formation via rhodium(III)-catalyzed oxidative C-H activation Chem. Soc. Rev, 2012;41:3651-3678.

${ }^{23}$ Verbeek J, Eriksson J, Syvänen S, Labots M, M de Lange EC, Voskuy RA, Mooijer MPJ, Rongen M, Lammertsma AA, Windhorst AD. [11C]- phenytoin revisited : synthesis by [11C]-CO carbonylation and first evaluation as a P-gp tracer in rats. EJNMMI Res.2012;2:36,1-11.

${ }^{24}$ Rotstein BH, Liang SH, Placzek MS, Hooker JM, Gee AD, Dollé F, Wilson AA, Vasdev N, [11C]CO bonds made easily for positron emissiontomography radiopharmaceuticals. Chem Soc Rev. 2016;45:4708-4726.

${ }^{25}$ Roeda D, Crouzel C, Van Der Jagt PJ, Van Zanten B, Comar D, Synthesis of [11C]-Urea for medical use Synthèse de l'urée [11C] pour usage medical, J. Appl. Radiat. Isot, 1980;31:549-551.

${ }^{26}$ Roeda D, Westera G. The synthesis of some [11C]-labelled antiepileptic drugs with potential utility as radiopharmaceuticals: Hydantoins and barbiturates J. Appl. Radiat. Isot., 1981;32:843-845.

${ }^{27}$ Labas R, Sobrio F, Bramoulle' Y, Herard AS, Guillermier M, Hantraye P, Dolle’' F, Barre L. Radiosynthesis of N - [ 4- ( 4 fluorobenzyl ) a NR2B-selective NMDA receptor antagonist. J. Label Compd. Radiopharm 2010;53:63-67.

${ }^{28}$ Schou, M. Halldin, C. Radiolabeling of two [11C]-labeled formylating agents and their application in the preparation of [11C] benzimidazole. J. Label Compd. Radiopharm 2012;55:460-462.

${ }^{29}$ Hooker JM, Reibel AT, Hill SM, Schueller MJ, Fowler JS. One-Pot, Direct Incorporation of $\left[11 \mathrm{C}^{\mathrm{C}} \mathrm{CO}_{2}\right.$ into Carbamates Angew. Chem., Int. Ed. 2009;48:3482-3485.

30 Wilson AA, Garcia A, Houle S, Vasdev N. Direct fixation of $[11 \mathrm{C}] \mathrm{CO}_{2}$ by amines: formation of [[11C]-carbonyl]methylcarbamates. Org.Biomol. Chem. 2010;8:428-432.

${ }^{31}$ Mossine AV, Brooks AF, Jackson IM, Quesada CA, Sherman P, Cole EL, Donnelly DJ, Scott PJH, Shao X. Synthesis of Diverse $11 \mathrm{C}$ - Labeled PET Radiotracers via Direct Incorporation of [11C]CO ${ }_{2}$. Bioconjugate Chem 2016;27:5,1382-1389.

${ }^{32}$ Haywood T, Kealey S, Sanchez-Cabezas S, Hall JJ, Allott L, Smith G, Plisson C, Miller PW. Carbon-11 Radiolabelling of Organosulfur Compounds : 11 C Synthesis of the Progesterone Receptor Agonist Tanaproget. Chem. Eur. J. 2015;21:90349038 .

${ }^{33}$ Miller PW, Bender D, [11C]Carbon Disulfide: AVersatile Reagent for PET Radiolabelling Chem. Eur. J. 2012;18:433436.

${ }^{34}$ Haywood T, Kealey S, Sánchez-Cabezas S, Hall JJ, Allott L, Smith G, Plisson C, Miller PW. Carbon-11 Radiolabelling of Organosulfur Compounds: [11C] Synthesis of the Progesterone Receptor Agonist Tanaproget Chem. Eur.J. 2015;21:9034 9038.

${ }^{35}$ Voges R, Heys JR, Moenius, T. in "Preparation of Compounds Labeled with Tritium and Carbon-14", John Wiley \& Sons, Ltd, 2009, 393.

${ }^{36}$ a) Penner N, Xu L, Prakash C, Radiolabeled Absorption, Distribution, Metabolism, and Excretion Studies in Drug Development: Why, When, and How? Chem. Res. Toxicol. 2012;25:513-531; b) Isin EM, Elmore CS, Nilsson GN, Thompson RA, Weidolf L, Use of Radiolabeled Compounds in Drug Metabolism and Pharmacokinetic Studies Chem. Res. Toxicol. 2012;25:532-542 c) Maxwell BD, Elmore CS, in "ADME-Enabling Technologies in Drug Design and Development" John Wiley \& Sons, Ltd, 2012, pp 461.

${ }^{37}$ Song F, Salter R, Chen L. Development of Decarboxylative Cyanation Reactions for C-13/C-14 Carboxylic Acid Labeling Using an Electrophilic Cyanating Reagent J. Org. Chem. 2017;82:3530-3537.

${ }^{38}$ Burrell RC, Easter JA, Cassidy MP, Gillman KW, Olson RE, Bonacorsi SJ Synthesis of carbon-14 and stable isotope labeled Avagacestat: a novel gamma secretase inhibitor for the treatment of Alzheimer's disease, J. Label. Compd. Radiopharm 2014;57:600-605.

${ }^{39}$ a) Tran SB, Maxwell BD, Chen SY, Bonacorsi SJ, Leith L, Ogan M, Rinehart JK, Balasubramanian B. Synthesis of lead LFA-1 antagonist [14C]spyrocyclic hydantoin. J. Label Compd Radiopharm 2009;52:236-242. b) Adams R, Levine I, Simplification of the gatterman synthesis of hydroxyl aldheydes J. Am. Chem. Soc, 1923;45:10,2373-2377. c) Adams R, Montgomery Edna, Simplification of the gatterman synthesis of hydroxyl aldheydes II, J. Am. Chem. Soc, 1924;46:6,15181521.

${ }^{40}$ Latli B, Hrapchak M, Gao JJ, Busacca CA, Senanayak CH, A novel five-lipoxygenase activity protein inhibitor labeled with carbon-14 and deuterium J. Label Compd. Radiopharm, 2015;58:390-394.

${ }^{41}$ Easter JA, Burrell RC, Bonacorsi SR Synthesis of isotopically labeled daclatasvir for use in human clinical studies, J. Label Compd. Radiopharm., 2016;59:164-170.

${ }^{42}$ Ortiz-Marciales M., Tirado LM., Colon R, Ufret ML, Figueroa R, Lebron M, DeJesis M, Martinez J, Malave T. N-tertButyldimethylsilyl Imines as Intermediates for the Synthesis of Amines and Ketones, Syn. Comm., 1998;21:4067-4075. 
43 Shirvani G, Shockravi A, Amini M, Saemian N. Synthesis of 2-(methylsulfonyl)-5-(4-(methylsulfonyl) phenyl)-4-phenyl-1H-[5- $\left.{ }^{14} \mathrm{C}\right]$ imidazole, a selective COX-2 inhibitor, via asymmetrical benzoins J. Label Compd. Radiopharm 2016;59:153-156.

${ }^{44}$ Hickey MJ, Allen PH, Kingston LP, Wilkinson DG, The synthesis of [14C]AZD5122. Incorporation of an IV14Cmicrotracer dose into a first inhuman study to determine the absolute oral bioavailability of AZD5122 J. Label. Compd. Radiopharm., 2016;59:245-249.

${ }^{45}$ Elmore CS, Landvatter S, Dorff PN, Powell ME, Killick D, Blake T, Hall J, Heys JR, Harding J, Urbanek R, Ernst G Synthesis of three alpha 7 agonists in labeled form J. Label. Compd. Radiopharm., 2014.;57:342-349.

${ }^{46}$ Traut RR, Bollen AA, Sun TTS, Hershey JWB, Sundberg J, Pierce LR, Methyl 4-mercaptobutyrimidate as a cleavable crosslinking reagent and its application to the Escherichia coli 30S ribosome Biochemistry, 1973;12:3266-3273.

${ }^{47}$ Wallace M, Allentoff AJ, Brailsford J, Gong S, Bonacorsi Jr S, Rinaldi F. Synthesis of 2-14C-iminothiolane and 2-13C,15N-iminothiolane (Traut's reagent) J. Label Compd. Radiopharm 2015;58:429-432.

${ }^{48}$ Latli B, Hrapchak M, Chevliakov M, Li G, Campbell S, Busacca CA, Senanayake CH, Synthesis of deleobuvir, a potent hepatitis C virus polymerase inhibitor, and its major metabolites labeled with carbon-13 and carbon-14 J. Label Compd. Radiopharm. 2015;58:250-260.

${ }^{49}$ Latli B, Hrapchak M, Eriksson M, Campbell S, Busacca CA, Senanayake CH, A potent IкB kinase- $\beta$ inhibitor labeled with carbon-14 and deuterium J. Label. Compd. Radiopharm. 2016;59:300-304.

${ }^{50}$ Loreau O, Camus N, Taran F, Audisio D, A Straightforward Access to [14C]- and [13C]-Labeled 2-Aminobenzoxazoles and Benzothiazoles via a KCN Polarity Inversion Strategy Synlett, 2016;27:1798-1802.

${ }^{51}$ Latli B, Reeves JT, Tan Z, Hrapchak M, Song JJ, Busacca CA, Senanayake CH, Synthesis of two potent glucocorticoid receptor agonists labeled with carbon-14 and stable isotopes, J. Label. Compd. Radiopharm. 2015;58:445-452.

${ }^{52}$ Tran SB, Maxwell BD, Burrell R, Bonacorsi Jr.SJ, The syntheses of isotopically labelled CB-1 antagonists for the treatment of obesity J. Label. Compd. Radiopharm. 2016;59:665-672.

53 Ren S, Gauthier D, Marques R, Helmy R, Hesk D, Synthesis of [14C]omarigliptin J Label. Comp. Radiopharm. 2016;59:386-390.

${ }_{55}^{54}$ Filer CN, Rodgers T, Synthesis of [7-14C]bergapten J. Label. Compd. Radiopharm. 2014;57:102-103.

55 Javaheri M, Shirvani G, Amini M, Saemian N, Saadatjoo N, Preparation of 1-fluoro-4-methyl-9H-[carbonyl-14C]thioxanthen-9-one and amine derivatives J. Label. Compd. Radiopharm. 2016;59:322324.

56 Saadatjoo N, Javaheri M, Saemian N, Amini M, Synthesis of the olanzapine labeled by carbon-14 J. Label Compd. Radiopharm. 2016;59:325-327.

${ }^{57}$ Soolingen JV, Verkruijsse HD, Keegstra MA, Brandsma L, Nickel-Catalyzed Cyanation of 2- and 3- Bromothiophene Synth. Commun, 1990;20:3153-3156.

${ }^{58}$ P. C. Lauterbur, 13C nuclear magnetic resonance spectra J. Chem. Phys., 1957; 26: 217.

59 a) K. M. Brindle. Imaging Metabolism with Hyperpolarized 13C-Labeled CellSubstrates J. Am. Chem. Soc. 2015: 137; 6418-6427 ; b) T. B. Rodrigues, E. M. Serrao, B. W. C. Kennedy, D.-E. Hu, M. I. Kettunen, K. M. Brindle, Magnetic resonance imaging of tumor glycolysis using hyperpolarized 13C-labeled glucoseNat. Med.2013: 20; 93 .

${ }^{60}$ La Clair JJ, Encoding matter with regiospecific 12C/13C isotopic labels Chem. Commun. 2018;54:2611-2614.

${ }^{61}$ Matwiyoff NA, McInteer BB, Mills TR Stable Isotope Production a distillation process Los Alamos Science 1983;65

${ }^{62}$ Hermange P, Lindhardt AT, Taaning RH, Bjerglund K, Lupp D, Skrydstrup T. Ex Situ Generation of Stoichiometric and Substoichiometric ${ }^{12} \mathrm{CO}$ and ${ }^{13} \mathrm{CO}$ and Its Efficient Incorporation in Palladium Catalyzed Aminocarbonylations. J. Am. Chem. Soc, 2011;133:15,6061-6071.

${ }^{63}$ Friis SD, Taaning RH, Lindhardt AT, Skrydstrup T, Silacarboxylic Acids as Efficient Carbon Monoxide Releasing Molecules: Synthesis and Application in Palladium-Catalyzed Carbonylation Reactions, J. Am. Chem. Soc, 2011;133:1811418117.

${ }^{64}$ Lescot C, Nielsen DU, Makarov IS,Lindhardt AT, Daasbjerg K, Skrydstrup T, Efficient Fluoride-Catalyzed Conversion of CO2 to CO at Room Temperature J. Am. Chem. Soc,2014;136:16,6142-6147.

${ }^{65}$ Lindhardt AT, Simonssen R, Taaning RH, GøgsigaGöran TM, Nilsson N, Stenhagen G, Elmore CS, Skrydstrup T, 14 Carbon monoxide made simple - novel approach to the generation, utilization and scrubbing of 14 carbon monoxide J. Label Compd. Radiopharm 2012;55:411-418.

${ }^{66}$ Neumann KT, Lindhardt AT, Bang-andersen B, Skrydstrup T, Access to 2-(Het) aryl and 2-Styryl Benzoxazoles via Palladium- Catalyzed Aminocarbonylation of Aryl and Vinyl Bromides. Org. Lett. 2015;17:2094-2097.

${ }^{67}$ Hermange P, Gøgsig TM, Lindhardt AT, Taaning RH, Skrydstrup T, Carbonylative Heck Reactions Using CO Generated ex Situ in a Two-Chamber System. Org. Lett. 2011;9:2444-2447.

${ }^{68}$ Gøgsig TM., Taaning RH, Lindhardt AT, Skrydstrup T, Palladium-Catalyzed Carbonylative a -Arylation for Accessing 1 , 3- Diketones. Angew. Chem. Int. Ed. 2012;51:798-801.

${ }^{69}$ Jusseau X., Yin H., Lindhardt AT, Skrydstrup T, Palladium-Catalyzed Carbonylative Coupling of ( 2-Azaaryl ) methyl anion Equivalents with ( Hetero ) Aryl Bromides. Chem. Eur. J. 2014;20:1-6.

${ }^{70}$ Burhardt MN, Ahlburg A, Skrydstrup T, Palladium-Catalyzed Thiocarbonylation of Aryl, Vinyl, and Benzyl Bromides J. Org. Chem., 2014;79:11830-11840.

${ }^{71}$ Andersen TL, Caneschi W, Ayoub A, Lindhardt AT, Couri MRC, Skrydstrup T, 1,2,4- and 1,3,4-Oxadiazole Synthesis by Palladium-CatalyzedCarbonylative Assembly of Aryl Bromides with Amidoximes orHydrazides Adv. Synth. Catal 2014;356:3074-3082.

${ }^{72}$ Neumann KT, Lindhardt AT, Bang B, Skrydstrup T, Synthesis and selective [2H]-,[13C]-, and [15N]-labeling of the Tau 
protein binder THK-523. J. Label Compd. Radiopharm 2017;60:30-35. 